\title{
PISA 2003 ve 2012 Matematik Okuryazarlığı Puanları- nın Ölçüt Geçerliği: Beklenti Tabloları ve Uyum Analizi
}

\author{
Abdullah Faruk KILIÇ, Başak ERDEM KARA, Nuri DOĞAN*
}

PISA 2003 VE 2012 Matematik Okuryazarlığı Puanlarının Ölçüt Geçerliği: Beklenti Tabloları Ve Uyum Analizi

\section{Özet}

Bu çalışmanın amacı PISA 2003 ve 2012 matematik okuryazarlı̆̆ puanlarının ölçüt geçerliğini beklenti tabloları ve uyum analizi yardımıyla araştırmaktır. Bu amaçla PISA 2003 ve 2012 problem çözme becerileri puanları kullanılmıştır. Puanlar 3 farklı şekilde kategorize edilmiştir. İlk olarak PISA tarafından kullanılan puan aralıkları kullanılmıştır. Ancak PISA puanlarını 357 ve altını da bir kategori kabul ederek 7 kategori oluşturulmuştur. Ayrıca puan aralıkları \%10 ve \%20'lik dilimlere bölünerek beklenti tabloları oluşturulmuş, damlacık grafikleriyle görsel olarak yorumlanması sağlanmış ayrıca kategoriler arasındaki uyumu incelemek için uyum analizi yapılmıştır. Araştırma sonucunda matematik puanlarının \%20'lik dilimler halinde kategorize edildiğinde $\% 10^{\prime}$ luk dilimlere göre daha uyumlu sonuçlar elde edildiği, beklenti tablolarında oranların yükseldiği gözlenmiştir. PISA puan kategorisinde matematik puan kategorileriyle problem çözme puanı kategorilerinin benzer olduğu söylenebilir.

Anahtar Kelimeler: Beklenti Tablosu, Uyum Analizi, PISA, Ölçüt Geçerliği

\section{Giriş}

Ekonomik İşbirliği ve Kalkınma Teşkilatı (Organization for Economic Cooperation and Development - OECD) tarafından düzenlenen Uluslararası Öğrenci Değerlendirme Programı (Programme for International Student Assesment - PISA), 15 yaş grubu öğrencilerin bugünün bilgi toplu-

*Abdullah Faruk KILIÇ, Arş. Gör., Hacettepe Üniversitesi, abdullahfarukkilic@gmail.com, Orcid ID: 0000-0003-31291763,Başak ERDEM-KARA, Arş. Gör., Hacettepe Üniversitesi, basakerdem@yahoo.com, Orcid ID: 0000-0003-3066-

2892, Nuri DOĞAN, Prof. Dr., Hacettepe Üniversitesi, nuridogan2004@gmail.com, Orcid ID: 0000-0001-6274-2016
Key Words: Expectancy Table, Correspondence Analysis, PISA, Criterion Validity

Criterion Validity of PISA 2003 and 2012 Mathematics Literacy Scores: Expectation Tables and Correspondance Analysis

Abstract

The purpose of this study was to investigate the criterion validity of PISA 2003 and 2012 mathematical literacy scores via expectation tables and correspondence analysis by using PISA 2003 and problem solving scores. Both scores were categorized in three different ways; PISA score intervals, dividing scores into $10 \%$ slices and $20 \%$ slices. For all of three categorizations, expectancy tables were obtained, visualized via bubble charts astly correspondence analysis were conducted to examine the correspondence between created categories. According to results, when categories were formed in $20 \%$ slices, correspondences between categories were higher than $10 \%$. It can be said that mathematical literacy and problem-solving categories were similar. 
munda karşılaşabilecekleri zorlukların üstesinden gelebilme noktasında ne derece hazırlıklı olduklarını ölçmeyi amaçlamaktadır. Bu programda, öğrencilerin belirli bir okul müfredatındaki alanlarda uzmanlaşmalarından ziyade, bilgi ve yeteneklerini gerçek hayatta karşılaşabilecekleri zorluklarla başa çıkmakta kullanabilmelerine odaklanılır. Uygulanmaya 2000 yılında başlanan PISA araştırmasına 32 ülke katılırken, Türkiye 2003 itibariyle araştırmaya dâhil olmuştur. Üç yılda bir yapılmakta olan PISA uygulamasında her dönem okuma, matematik ve fen bilimleri alanlarından biri temel alan olarak belirlenmekte ve bu alana daha fazla ağırlık verilmektedir. 2000 yılında yapılan ilk uygulamada, okuma, matematik ve fen okuryazarlık alanları araştııımış, odak noktası okuma becerileri olmuştur. 2003'te ağırlıklı alan olarak matematik alınırken, 2006'da fen, 2009'da ise okuma becerileri tekrar ağılıklı alan olmuş ve döngü bu şekilde devam etmiştir (OECD, 2005a, 2014; Taş, Arıcı, Ozarkan ve Özgürlük, 2016).

PISA uygulamasında okuma, fen ve matematik alanlarına ek olarak zaman zaman farklı yeterlikler de değerlendirmeye alınmaktadır. Örneğin; PISA 2003'te problem çözme, 2012'de yaratıcı problem çözme ve finansal okuryazarlık, 2015 yılında ise işbirlikli problem çözme ve finansal okuryazarlık becerilerine ilişkin değerlendirmelere yer verilmiştir. 2012'de bilgisayar ortamında uygulanan yaratıcı problem çözme değerlendirmesi katılan ülkelerin $2 / 3$ 'üne uygulanmıştır. Ancak yine de değerlendirmenin temel bileşenlerinden biri olarak kabul edilmiştir. PISA 2015'teki işbirlikli problem çözme ve finansal okuryazarlık değerlendirmelerine de sadece katılmak isteyen ülkeler alınmıştır (OECD, 2005a, 2014, 2017; Taş ve diğerleri, 2016).

Problem çözme becerisi; bireylerin, çözüm yönteminin hemen görülebilecek şekilde açık ve net olmadığı gerçek ve disiplinler arası problem durumlarını anlamak ve çözmek için bilişsel süreçlere dâhil olabilme kapasiteleri olarak tanımlanmaktadır (Autor, Levy ve Murnane, 2003; OECD, 2005a, 2014; The National Council of Teachers of Mathematics (NCTM), 2000). Problem çözme sürecinde bireylerden yeni ortamlarda çalışmaları, daha önce karşılaşmadıkları problemlerle yüzleşmeleri ve belirli kapsamlara bağı olmayan genel alan akıl yürütme becerilerini uygulamaları beklenir. OECD (2017) raporunda, problem çözme becerisinin, modern toplumumuzda en çok gerekli olan 21. yüzyıl becerilerinden biri olduğu belirtilmiştir. Problem çözme becerileri bugünün ekonomisinde artan şekilde ihtiyaç duyulmakta iken, yeni durumlara uyum sağlayabilme yeteneği, yaşam boyu öğrenme ve bilgiyi eyleme dönüştürebilme toplumda önemli olmuştur. Bugünün toplumunda işyerlerinde, sıradan olmayan problemleri çözebilen insanlara talep vardır. Özellikle hızlı büyüyen, idari ve teknik mesleklerde karmaşık problem çözme becerileri talep edilmektedir. Bilgisayarlar ve makineler rutin görevleri hali hazırda yapabildikleri için, bunları yapan işçilere daha az ihtiyaç duyulmaktadır. Bunun yerine, beklenmeyen ve aşina olunmayan işlerle baş edebilen çalışanlar tercih sebebidir (Autor ve diğerleri, 2003; OECD, 2014).

Benzer şekilde PISA 2012 raporunda, eğitimde odaklanılan noktanın öğrencileri rutin becerilerle donatmaktan ziyade karmaşık ve rutin olmayan bilişsel zorluklarla yüzleşme ve üstesinden gelecek şekilde güçlendirme yönünde kayma gösterdiği belirtilmiştir. Öğrencilerden hazır çözümleri olmayan problemleri çözmeleri istendiğinde, çözümün önünde duran bariyerleri nasıl aşabilecek- 
leri konusunda esnek ve yaratıc düşünmeleri beklenmektedir. Yapılan çalışmalar, PISA gibi problem çözme becerisi değerlendirmelerinde incelenen genel becerilerin akademik başarı ile yüksek derecede ilişkili olduğunu göstermiştir (Greiff, Holt ve Funke, 2013; Wüstenberg, Greiff ve Funke, 2012).

PISA matematik okuryazarlığı ise, bireyin sağlam temelli yargılarda bulunmak ve hayattaki ihtiyaçlarını karşılayacak şekilde matematiği kullanabilmek konusunda matematiğin dünyada oynadığı rolü anlama ve belirleme kapasitesi olarak tanımlanmıştır. Bu bağlamda, matematik okuryazarlığı hayattaki ihtiyaçların karşılanması ile ilişkilidir. PISA matematik okuryazarlığı alanı, öğrencilerin farklı durumlardaki matematik problemlerini formülleştirirken, çözerken ve yorumlarken analiz etme, fikirleri ilişkilendirme ve ifade etme kapasiteleri ile ilişkilidir (Thomson, Hillman ve De-Bortoli, 2013).

NCTM (2000)'ye göre problem çözme becerisi bütün matematik öğrenmelerinin ayrılmaz bir parçasıdır. Okul öncesinden üniversiteye kadar öğretim programları, öğrencilerin problem çözme yoluyla yeni matematiksel bilgileri oluşturabilecekleri şekilde kurgulanmalıdır. Öğrencilerin karşılaştıkları problemlere çözüm bulmak için matematiksel bilgilerini kullanmaları ve bu süreç boyunca yeni matematiksel anlamalar geliştirmeleri sağlanmalıdır. Matematikte problem çözmeyi öğrenme yoluyla öğrencilerin, düşünme yolları, merak alışkanlığı ve tanıdık olmayan durumlara karşı güven geliştirmelerine yardımc olunmalıdır. Günlük yaşamda ve iş hayatında iyi bir problem çözücü olmak büyük avantajlar sağlayabilmektedir. İyi problemler birçok konuyu birleştirecek ve önemli düzeyde matematik içerecektir (NCTM, 2000).

PISA 2003 ve 2012 değerlendirmelerinden elde edilen sonuçlar incelendiğinde, problem çözme becerisi yüksek olan bireylerin diğer alanlarda da iyi sonuç aldıkları; zayıf bireylerin ise diğer alanlardaki sonuçlarının da zayıf olduğu gözlenmiş̧ir. Problem çözme becerisi en yüksek korelasyonu ise matematik okuryazarlığı alanı ile göstermiştir. Problem çözme becerisi ve diğer alanların korelasyon değerleri Tablo 1'de sunulmuştur (OECD, 2004, 2014).

Tablo 1. Problem Çözme Becerisi Ile Diğer Alanlar Arasındaki Korelasyonlar

\begin{tabular}{llll}
\hline \hline & Matematik & Fen & Okuma \\
\hline PISA 2003 Problem çözme & 0.89 & 0.82 & 0.80 \\
PISA 2012 Problem çözme & 0.81 & 0.78 & 0.75 \\
\hline
\end{tabular}

Her iki uygulamada da problem çözme becerisinin matematik okuryazarlığıyla en yüksek ilişkide olduğu görülmektedir.

Verilen bilgiler doğrultusunda, problem çözme becerilerinin günlük hayattaki önemi ve akademik becerilerle ilişkili olduğu görülmektedir. Özellikle matematik alanıyla yakın bir ilişki içerisin- 
dedir. Dolayısıyla, matematik okuryazarlığı testinde yüksek puana sahip bireylerin, problem çözme becerisi puanlarının da yüksek olması beklenmektedir.

PISA, problem çözmede temel bilişsel süreçlere odaklanmak için belli bir alana yönelik bilgi gereksiniminden mümkün olduğunca kaçınmaktadır. Bu durum, PISA'da ölçülen diğer alanların problem çözmeden ayrımasını sağlamaktadır (OECD, 2013). Ancak matematik ile problem çözme arasında pozitif yönde bir ilişki olduğu hem korelasyonlardan hem de yapılan diğer çalışmalardan anlaşılmaktadır. Nitekim Yavuz ve Çetin (2017) tarafından yürütülen araştırmanın odak noktasını Türkiye ile Sırbistan'ın matematik puanları açısından benzer olmasına rağmen problem çözme becerileri açısından iki ülke arasında fark olması oluşturmaktadır. Ayrıca Akyüz ve Pala (2010) tarafından yürütülen araştırmada da matematik okuryazarlığı ve problem çözme arasında yüksek etki büyüklüğünde anlamlı ilişki olduğu raporlanmıştır. OECD (2013) tarafından da belirtildiği gibi problem çözme ayrı bir alan olmasına rağmen matematiksel düşünceyle iç içe olması mevcut araştırmada matematik puanlarının geçerliğine yönelik kanıt toplama sürecinde bir kriter olarak kullanılmasını sağlamıştır.

Bu noktalardan yola çıkılarak, PISA matematik testi puanlarının ölçüt ilişkili geçerliğinin PISA problem çözme testi aracılı̆ıyla incelenebileceği düşünülmüştür. Ölçüt ilişkili geçerlik, test puanlarının ilgilenilen yapının göstergesi olduğu düşünülen dışsal ölçütlerle ilişki düzeyini ifade etmektedir. Test puanları ve ölçüt puanları arasındaki korelasyon, test puanlarına dayalı olarak alınacak kararların geçerliği noktasında kanıt sağlar (Murphy ve Davidshofer, 2004; Sireci, 2005). Crocker ve Algina (2008), ölçüt ilişkili geçerliğin iki türü olduğundan bahsetmiştir; yordama geçerliği ve zamandaş (uygunluk) geçerliği. Yordama geçerliğinde ölçüt puanları, geçerliği araştırılan test puanlarından daha sonra elde edilirken, zamandaş geçerlikte ölçüt puanları test puanları ile aynı anda toplanır (Crocker ve Algina, 2008; Sireci, 2005). PISA Matematik okuryazarlı̆̆ı puanlarının ölçüt geçerliğinin belirlenmesi amacıyla yürütülen bu araştırmada PISA 2003 ve 2012 matematik ve problem çözme beceri puanları kullanılmıştır. Bu testler aynı anda uygulandığı için, çalışma kapsamında incelenen ölçüt geçerliği türü zamandaş geçerliktir. PISA 2003 ve 2012 yıllarında matematik odaklı olarak gerçekleştirildiği için araştırmaya bu yıllar dâhil edilmiştir. Mevcut yıllardaki problem çözme becerileri ise ölçüt puanı olarak ele alınmıştır.

Literatür incelendiğinde PISA ile ilgili birçok çalışma olmasına rağmen matematik okuryazarlığı puanlarının ölçüt geçerliğine yönelik kanıt arama sürecinin çalışılmadığı gözlenmiştir. Bu nedenle araştırmanın amacı, matematik okuryazarlığının ağırlıklı alan olduğu ve problem çözme testinin de uygulandığı PISA 2003 ve 2012 değerlendirmesine göre Türkiye örnekleminde, öğrencilerin matematik okuryazarlığı ve problem çözme becerisi arasındaki uyumun incelenmesi yoluyla, matematik testi puanlarının ölçüt geçerliğinin belirlenmesidir. Bu amaçla, matematik okuryazarlığı ve problem çözme becerisi puanları yüzdelik dilimler (\%10 ve \%20) ve OECD değerlendirme kategorilerine göre ayrı ayrı gruplandırımış ve bu gruplardaki bireylerin uyumu incelenmiştir. Bu amaç doğrultusuna aşağıdaki problem cümlelerine yanıt aranmıştır; 
- PISA 2003 ve 2012 değerlendirmelerinden elde edilen matematik ve problem çözme puanları \%10'luk dilimler halinde on gruba ayrıldığında, gruplardaki bireylerin eşleşme yüzdesi ve uyum analizi sonuçları nasıldır?

- $\quad$ PISA 2003 ve 2012 değerlendirmelerinde elde edilen matematik ve problem çözme puanları \%20'lik dilimler halinde beş gruba ayrıldığında, gruplardaki bireylerin eşleşme yüzdesi ve uyum analizi sonuçları nasıılır?

- $\quad$ PISA 2003 ve 2012 değerlendirmelerinde elde edilen matematik ve problem çözme puanları OECD değerlendirme kategorilerine göre altı gruba ayrıldığında, gruplardaki bireylerin eşleşme yüzdesi ve uyum analizi sonuçları nasıldır?

\section{Yöntem}

PISA Matematik puanlarının ölçüt geçerliğinin belirlenmesi amacıyla yürütülen bu araştırmada genel tarama modeli kullanılmıştır. Tarama araştırmaları bir değişiklik yapma amacı gütmeden olan durumu betimlemek için yürütülen araştırmalardır (Karasar, 2014). Ayrıca düzeyi açısından mevcut araştırma betimsel bir araştırma olarak değerlendirilebilir.

\subsection{Evren ve örneklem}

Araştırmanın verilerini, PISA 2003 için Türkiye'den bu uygulamaya katılan 4855 ve PISA 2012 için Türkiye'den bu uygulamaya katılan 4848 bireyin verileri oluşturmaktadır. Veriler, OECD'nin web sayfasından alınmıştır (OECD, 2005b, 2015).

\subsection{Veri analizi}

PISA 2003 ve 2012 matematik puanlarının ölçüt geçerliğinin belirlenmesi amacıyla beklenti tabloları ve uyum analizi kullanılmıştır. Ayrıca verilerin anlaşılır olmasını sağlamak için grafikler kullanımıştır. Veri analizi için öncelikle puan aralıkları belirlenmiştir. Bunun için üç farklı puan aralığına göre araştırma yapılmıştır. Birinci olarak $\operatorname{OECD~}(2005 \mathrm{a}, 2013)$ tarafından belirtilen düzeyler kullanılmıştır (357 puan ve altı 0, 358-420 aralı̆ı 1, 421-482 aralığı 2, 483-545 aralığı 3, 546-607 aralığı 4, 608-669 aralığı 5 ve 670 ve üstü ise 6). Ancak PISA 2003 matematik puanları 3 kategoriye ayrıldığı için PISA 2012'ye benzer şekilde puan kategorileri düzenlenmiştir. İkinci olarak matematik ve problem çözme puan aralığı \%10'luk dilimlere ayrılarak 10 kategori, üçüncü olarak matematik ve problem çözme puan aralığı \%20'lik dilimlere ayrılarak 5 kategori oluşturulmuştur. Böylece değerlendirmeler bu üç farklı kategori ayrımına göre yapılmıştır.

\subsubsection{Beklenti tabloları}

Beklenti tabloları; ölçüt geçerliğinin araştırımasında kullanılan, anlaşılması kolay ve basit olan ancak önemli bilgiler veren bir yöntemdir. Beklenti tabloları, test puanları ile başka bir değişkenden elde edilen (uzman görüşü, işe alınıp alınmama vb) sonuçlar arasındaki ilişkileri gösteren tablolardır (Murphy ve Davidshofer, 2004). Diğer bir ifadeyle bir değişken için tanımlanan alt gruplara ait olan bireylerin, başka bir değişken temelinde tanımlanan alt gruplara ait olma olasılığı üzerinden iki değişken arasındaki ilişkiyi gösteren tablolardır (Schrader, 1965). 
Beklenti tabloları oluşturulurken birbiriyle ilişkili olan değişkenler seçilir. Örneğin matematik puanı ile istatistik dersinden geçme dereceleri arasındaki ilişki beklenti tablolarıla incelenerek ölçüt geçerliği çalışması yürütülebilir. Bu durumda matematik puanları ile istatistik dersinden alınan geçme dereceleri (AA, BA vb) çapraz tabloda ifade edilerek incelenir. Beklenti tabloları, hücrelerdeki birey yüzdesiyle oluşturulabileceği gibi bireylerin o hücrede olma ihtimalleri üzerinden de oluşturulabilir (Murphy ve Davidshofer, 2004). Örneğin matematik dersinden 60-65 arasında puan alan bireylerin istatistikten BB ile geçme olasılıkları, çapraz tabloda bu hücrede bulunan birey sayısı ile satır toplamının oranı olarak ifade edilebilir.

Beklenti tablolarının asıl avantajı iki değişken arasındaki ilişkiyi basit bir şekilde anlama imkânı vermesidir. Ancak beklenti tablolarının kullanımında; örneklemin geniş olması ve değişkenler arasındaki ilişkinin yüksek olması önerilmektedir (Latham ve Whyte, 1994; Murphy ve Davidshofer, 2004). Çünkü ancak bu durumda beklenti tablolarındaki olasılıklara güvenilebilir. Eğer iki değişken arasındaki korelasyon düşükse, beklenti tablolarının kullanılması uygun olmayabilir.

Araştırmada kullanılan 2003 ve 2012 yıllarında gerçekleştirilen PISA'nın problem çözme becerisi puanları ile matematik puanları arasındaki korelasyonun belirlenmesi için PV1 (plausible value) değerleri kullanılmıştır. Bu amaçla öncelikle problem çözme becerisi ve matematik PV1 puanlarının dağılımı incelenmiştir. PISA 2003 için, problem çözme becerisi puanlarının çarpıklık katsayısı 0.249, basıklık katsayısı ise 0.477; matematik puanlarının çarpıklık katsayısı 0.472, basıklık katsayısı ise 0.517 olarak gözlenmiştir. PISA 2012 için, problem çözme becerisi puanlarının çarpıklık katsayısı 0.166, basıklık katsayısı ise -0.193; matematik puanlarının çarpıklık katsayısı 0.434, basıklık katsayısı ise -0,147 olarak gözlenmiştir. Buna göre değişkenlerin normal dağıldığı ifade edilebilir (Hancock ve Mueller, 2013; Tabachnik ve Fidell, 2012). Değişkenler normal dağıldığı için Pearson Momentler Çarpımı korelasyon katsayısı ile değişkenler arasındaki korelasyon hesaplanmıştır. Buna göre PISA 2003 için problem çözme becerisi puanları ile matematik puanları arasındaki korelasyon 0.883 olarak elde edilmiş olup $\alpha=0.01$ düzeyinde anlamlıdır. Benzer şekilde hesaplanan PISA 2012 için problem çözme becerisi puanları ile matematik puanları arasındaki korelasyon 0.840 olarak elde edilmiş olup $\alpha=0.01$ düzeyinde anlamlı olduğu gözlenmiştir. Bu sonuçlara göre iki değişken için beklenti tablolarının kullanılmasının uygun olduğu söylenebilir.

\subsubsection{Uyum analizi}

Uyum analizi, iki ya da daha çok boyutlu çapraz tablolar kullanılarak değişkenler arasındaki ilişkilerin incelendiği ve tanımlayıcı tipte olan çok değişkenli istatistiksel bir yöntemdir (Alpar, 2013). Diğer bir deyişle uyum analizi, iki ya da daha çok kategoriye sahip veriler arasındaki uyumun incelenmesinde kullanilır (Bartholomew, Steele, Moustaki ve Galbraith, 2008). Bu yöntemin çapraz tablolardaki sayıların pozitif olması dışında varsayımının bulunmaması (Alpar, 2013; Clausen, 1998), yöntemin kullanışı olmasını sağlamaktadır.

Uyum analizinin temel kavramları; profil, ağırlık, ki-kare ve öklit uzaklığı ile inertia'dır. Profiller frekansların oranlara dönüştürülmesi ile elde edilir. Hem satır hem de sütun profilleri hesaplanır. 
Daha sonra satır ve sütun toplamları tüm toplama oranlanarak ağırlıklar elde edilir (Alpar, 2013). Ağılıklandırmanın amacı her bireyin profil noktasına eşit katkıda bulunmasını sağlamaktır (Greenacre, 2007). Bu aşamadan sonra ki-kare uzaklı̆ı satır ve sütun ağıllıklıları kullanılarak hesaplanır. Hesaplanan ki-kare uzaklığı yardımıyla varyans kavramının yerine kullanılan inertia değeri hesaplanır. Daha sonra hesaplanan inertia değerlerinin sıfırdan farklı olup olmadığı ki-kare testiyle test edilir. Bu önemlilik testi uyum iyiliği testi olmayıp inertia'nın (değişkenliğin) sıfırdan farklı olup olmadığını test eder (Bendixen, 1996). Inertia'nın sıfırdan farklı olması satır ve sütun arasında ilişki olduğunu göstermektedir (Alpar, 2013). Buna göre araştırmadaki kullanılan PISA 2003 matematik puan kategorileri ile problem çözme becerisi puan kategorileri arasındaki ilişkiyi belirlemeye yönelik olarak yürütülen uyum analizi sonucunda inertianın sıfırdan farklı olduğu gözlenmiştir ([PISA kategorilerine göre: $\left.\chi^{2}(36)=7370.84, p<0,05\right]$, [\%10'luk kategorilere göre: $\chi^{2}(81)=7294.82, p<0,05$ ], [\%20'lik kategorilere göre: $\left.\left.\chi^{2}(16)=5256.58, p<0,05\right]\right)$. Buna göre matematik puan kategorileri ile problem çözme becerisi puan kategorileri arasında ilişki olduğu söylenebilir. Ayrıca iki boyutlu çözümde PISA kategorilerine göre incelendiğinde inertia'nın \%83.6'sının, \%10'luk dilimlere göre incelendiğinde $\% 80.7$ 'sinin, \%20'lik dilimlere göre incelendiğinde \%93.3'ünün açıklandığı gözlenmiştir.

Benzer şekilde PISA 2012 matematik puan kategorileri ile problem çözme becerisi puan kategorileri arasındaki ilişkiyi belirlemeye yönelik olarak yürütülen uyum analizi sonucunda inertianın sıfırdan farklı olduğu gözlenmiştir ([PISA kategorilerine göre: $\left.\chi^{2}(36)=5888.75, p<0,05\right],\left[\% 10^{\prime} / u k\right.$ kategorilere göre: $\chi^{2}(81)=5852.78, p<0,05$ ], [\%20'lik kategorilere göre: $\left.\left.\chi^{2}(16)=4580.19, p<0,05\right]\right)$. Buna göre matematik puan kategorileri ile problem çözme becerisi puan kategorileri arasında ilişki olduğu söylenebilir. Ayrıca iki boyutlu çözümde PISA kategorilerine göre incelendiğinde inertia'nın \%83.6'sının, \%10'luk dilimlere göre incelendiğinde \%87.4'ünün, \%20'lik dilimlere göre incelendiğinde \%96.0'ının açıklandığı gözlenmiştir.

Araştırmada kullanılan yöntemlerden beklenti tabloları ve uyum analizi için SPSS programı kullanılmıştır. Ayrıca beklenti tablolarının daha anlaşılır ve görsel olarak da sunulabilmesi amacıyla damlacık grafikleri oluşturulmuştur. Damlacık grafiklerinin oluşturulmasında XLSTAT programı kullanılmıştır.

\section{Bulgular ve Yorum}

Bu bölümde alt problemlere göre bulgulara yer verilmiştir.

3.1 Matematik ve problem çözme puanları \%10'luk dilimler halinde on gruba ayrılarak incelenmesi

PISA 2003 değerlendirmelerinden elde edilen matematik ve problem çözme puanları \%10'luk dilimler halinde on gruba ayrımış ve bireylerin eşleşme sayıları ile eşleşme yüzdeleri beklenti tablosu olarak Tablo 2'de sunulmuştur. 
Abdullah Faruk KILIÇ | Başak ERDEM KARA | Nuri DOĞAN

Tablo 2. PISA 2003 Matematik ve Problem Çözme Puanları \%10’luk Kategorilere Göre Dağılımı

\begin{tabular}{|c|c|c|c|c|c|c|c|c|c|c|c|c|}
\hline \multirow{2}{*}{\multicolumn{2}{|c|}{ Kategoriler }} & \multicolumn{10}{|c|}{ Matematik Puan Kategorileri } & \multirow[b]{2}{*}{ Toplam } \\
\hline & & 1 & 2 & 3 & 4 & 5 & 6 & 7 & 8 & 9 & 10 & \\
\hline \multirow{15}{*}{ 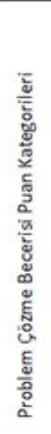 } & \multirow[t]{2}{*}{1} & 294 & 114 & & & & & & & 0 & 0 & 491 \\
\hline & & $\begin{array}{l}(60.1) \\
114\end{array}$ & $\begin{array}{l}(24) \\
141\end{array}$ & $\begin{array}{c}46(9.3) \\
114\end{array}$ & $\begin{array}{c}24(5.1) \\
64\end{array}$ & $\begin{array}{c}6(1.2) \\
40\end{array}$ & $4(0.9)$ & $1(0.2)$ & $2(0.4)$ & $\begin{array}{l}\text { (0) } \\
0\end{array}$ & $\begin{array}{l}(0) \\
0\end{array}$ & $\begin{array}{c}(10.1) \\
491\end{array}$ \\
\hline & 2 & $(23.3)$ & $(29.7)$ & (23.1) & (13.5) & (8) & $13(2.8)$ & $3(0.6)$ & $2(0.4)$ & (0) & (0) & (10.1) \\
\hline & \multirow{3}{*}{3} & 44 & 114 & 105 & 83 & 83 & & & & 0 & 0 & 478 \\
\hline & & (9) & (24) & (21.3) & $(17.5)$ & (16.6) & $34(7.3)$ & $8(1.6)$ & $7(1.4)$ & (0) & (0) & (9.8) \\
\hline & & & 59 & 104 & 108 & 81 & 73 & & & & 0 & 486 \\
\hline & 4 & $18(3.7)$ & $(12.4)$ & (21.1) & $(22.8)$ & (16.2) & $(15.6)$ & $24(4.8)$ & $16(3.3)$ & $3(0.6)$ & (0) & (10) \\
\hline & \multirow[t]{2}{*}{5} & $11(2.2)$ & $33(6.9)$ & 64 (13) & $\begin{array}{c}89 \\
(18.8)\end{array}$ & $\begin{array}{l}94 \\
\text { (18.8) }\end{array}$ & $\begin{array}{c}77 \\
(16.5)\end{array}$ & $\begin{array}{c}65 \\
(13.1)\end{array}$ & $29(5.9)$ & $12(2.5)$ & $1(0.2)$ & $\begin{array}{l}475 \\
(9.8)\end{array}$ \\
\hline & & & & & 54 & 92 & 98 & 104 & 68 & & & 487 \\
\hline & 6 & $6(1.2)$ & $11(2.3)$ & $33(6.7)$ & (11.4) & (18.4) & $(20.9)$ & (20.9) & (13.9) & $20(4.1)$ & $1(0.2)$ & (10) \\
\hline & \multirow[t]{2}{*}{7} & & & & & 72 & 85 & 117 & 98 & 65 & & 499 \\
\hline & & $1(0.2)$ & $3(0.6)$ & $22(4.5)$ & $32(6.8)$ & (14.4) & $(18.2)$ & (23.5) & $(20.1)$ & (13.5) & $4(0.8)$ & (10.3) \\
\hline & \multirow[t]{2}{*}{8} & $1(0,2)$ & $0(0)$ & $5(1)$ & $17(3.6)$ & $28(5.6)$ & 62 & 128 & 119 & 104 & & 485 \\
\hline & & $1(0.2)$ & $0(0)$ & $3(1)$ & $17(3.0)$ & $28(5.6)$ & (13.2) & $(25.8)$ & $\begin{array}{l}(24.4) \\
118\end{array}$ & $\begin{array}{l}(21.6) \\
187\end{array}$ & $\begin{array}{c}21(4.3) \\
105\end{array}$ & $\begin{array}{l}(10) \\
477\end{array}$ \\
\hline & 9 & $0(0)$ & $0(0)$ & $0(0)$ & $2(0.4)$ & $5(1)$ & $17(3.6)$ & $43(8.7)$ & (24.2) & (38.8) & (21.5) & (9.8) \\
\hline & \multirow{2}{*}{10} & & & & & & & & & 91 & 356 & 486 \\
\hline & & $0(0)$ & $0(0)$ & $0(0)$ & $1(0.2)$ & $0(0)$ & $5(1.1)$ & $4(0.8)$ & $29(5.9)$ & (18.9) & (73) & (10) \\
\hline \multirow{2}{*}{\multicolumn{2}{|c|}{ plam }} & 489 & 475 & 493 & 474 & 501 & 468 & 497 & 488 & 482 & 488 & 4855 \\
\hline & & $(10.1)$ & $(9.8)$ & $(10.2)$ & $(9.8)$ & $(10.3)$ & (9.6) & (10.2) & $(10.1)$ & (9.9) & $(10.1)$ & (100) \\
\hline
\end{tabular}

Tablo 2'de matematik ve problem çözme puanları \%10'luk kategorilere göre dağılımları bulunmaktadır. Tablo 2'de kategorilerdeki birey sayıları ve parantez içinde de bu sayıların sütunlardaki toplam birey sayısı içindeki yüzdesi verilmiştir. Böylece matematik puan kategorilerindeki bireylerin yüzde kaçının problem çözme becerisi kategorilerinde yer aldığı incelenmiştir. Örneğin, matematik puanı bakımından 1. Kategoride yer alan bireylerin \%23.3'ü problem çözme becerisinde 2. Kategoride yer almaktadır. Bu rakamlar incelendiğinde, alt ve üst kategorilerde uyum daha fazlayken ortadaki kategorilerde uyum daha düşük olduğu söylenebilir. Hem problem çözme hem de matematik puanlarına göre aynı kategoride olan bireyler incelendiğinde birinci kategori için \%60.1, ikinci kategori için \%29.7, üçüncü kategori için \%21.3, dördüncü kategori için \%22.8, beşinci kategori için \%18.8, altıncı kategori için \%20.9, yedinci kategori için \%23.5, sekizinci kategori için \%24.4, dokuzuncu kategori için \%38.8 ve onuncu kategori için \%73 olduğu görünmektedir. Genel uyum tüm kategorilerdeki uyumlu bireylerin yüzdesi olarak değerlendirildiğinde \%33.4 olduğu söylenebilir. Beklenti tablosu olasılık anlamı da taşıdığından örneğin matematik puanı açısından 7. kategoride bulunan bir bireyin problem çözme puanı açısından 7. kategoride olma olasılığı \%23.5'tir (117/497=0.235). Benzer şekilde düşünüldüğünde 8. Kategoride olma olasıllğı ise \%20.1'dir (98/488=0.201). Tablo 2'ye göre oluşturulan damlacık grafiği Şekil 1'de sunulmuştur. 


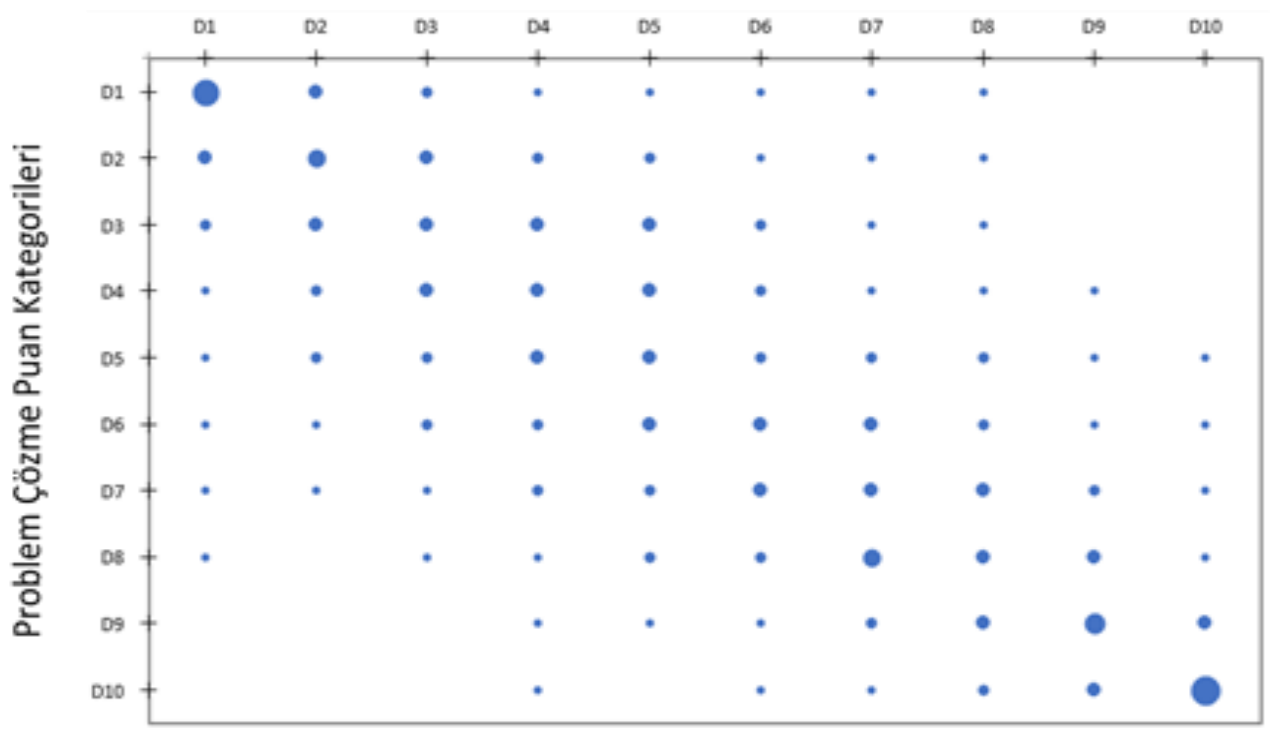

Matematik Puan Kategorileri

Şekil 1. PISA 2003 Matematik ve Problem Çözme Puanları \%10’luk Dilim Karşılaştırılması

Şekil 1 incelendiğinde uç kategorilerdeki puanların daha fazla uyum içinde olduğu ancak orta kategorilerin daha az uyum içinde olduğu görülmektedir. Buna ek olarak, köşegendeki baloncuklara yakın baloncukların da diğerlerine nazaran daha büyük olduğu söylenebilir. Bu durum, kategoriler içerisinde birebir eşlenme olmasa da bireylerin yakın kategoriler içerisinde bulundukları anlamına gelebilir. Damlacık grafiğinde damlacıkların boyutu büyüdükçe aynı kategorideki birey sayısının daha fazla olduğu anlamına gelmektedir. Buna göre damlacıklar incelendiğinde problem çözme becerisi açısından 8. kategoride olan bireyin matematik puanı açısından 7. Kategoride olma olasılığının daha yüksek olduğu söylenebilir. Çünkü belirtilen yerdeki damlacık her iki alanda da 8. kategoride olan bireylerden daha büyüktür. Bireylerin \%10'luk puan dilimine göre matematik ve problem çözme puanları arasındaki uyumun belirlenmesine yönelik yürütülen uyum analizi sonucunda değişken kategorilerinin düzlemde gösterimi Şekil 2'de sunulmuştur. 


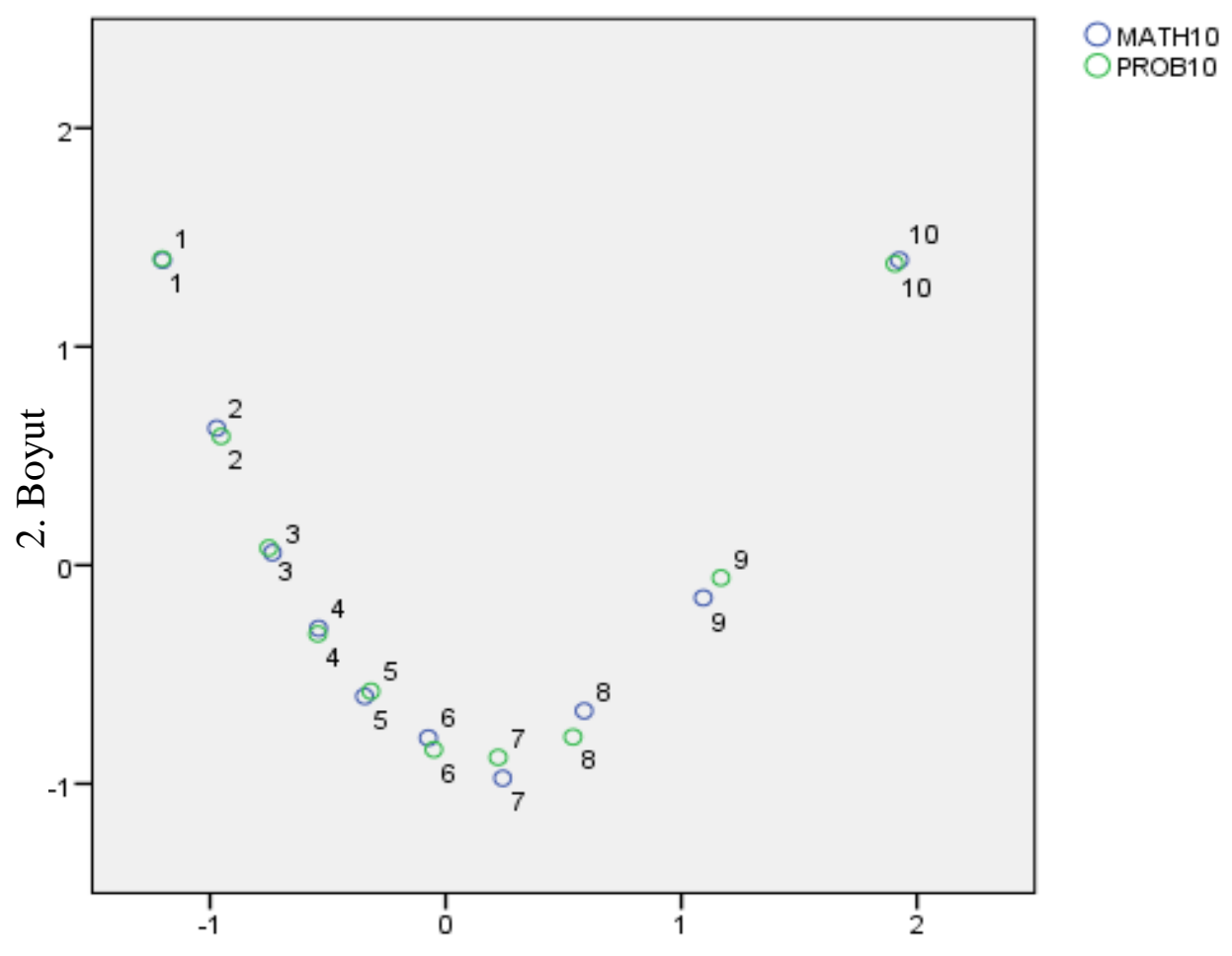

\section{Boyut}

Şekil 2. PISA 2003 Matematik ve Problem Çözme Puanları \%10'luk Puan Dilimine Göre Değişken Kategorilerinin Düzlemde Gösterimi

Şekil 2 incelendiğinde uyum analizi sonucunda ortadaki kategorilerdeki bireylerde uyumun azaldığı görülmektedir. Ancak dikkat çekici bir bulgu olarak üst kategorideki bireyler arasındaki uyumsuzluğun daha fazla olduğu söylenebilir. Çünkü uyum analizi tüm dağııımı dikkate almaktadır. Sadece kesişim noktasının dağılımını değil, hem matematik hem de problem çözme kategorilerinin karşııılı dağılımlarını da dikkate alarak hesaplamaları gerçekleştirir. Bu nedenle üst kategorilerdeki uyumun daha az olduğu söylenebilir. PISA 2012 değerlendirmelerinden elde edilen matematik ve problem çözme puanları \%10'luk dilimler halinde on gruba ayrılmış ve bireylerin eşleşme sayıları ile eşleşme yüzdeleri beklenti tablosu olarak Tablo 3'te sunulmuştur. 
Tablo 3. PISA 2012 Matematik ve Problem Çözme Puanları \%10'luk Kategorilere Göre Dağılımı

\begin{tabular}{|c|c|c|c|c|c|c|c|c|c|c|c|c|}
\hline \multirow{2}{*}{\multicolumn{2}{|c|}{ Kategoriler }} & \multicolumn{10}{|c|}{ Matematik Puan Kategorileri } & \multirow[b]{2}{*}{ Toplam } \\
\hline & & 1 & 2 & 3 & 4 & 5 & 6 & 7 & 8 & 9 & 10 & \\
\hline \multirow{11}{*}{ 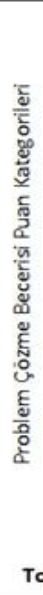 } & 1 & $\begin{array}{c}258 \\
(52.5)\end{array}$ & $\begin{array}{c}115 \\
(24.5)\end{array}$ & $\begin{array}{c}59 \\
(11.5)\end{array}$ & $\begin{array}{l}20 \\
(4.3)\end{array}$ & $\begin{array}{c}18 \\
(3.7)\end{array}$ & $8(1.7)$ & $\begin{array}{c}0 \\
\text { (0) }\end{array}$ & $\begin{array}{c}0 \\
\text { (0) }\end{array}$ & $\begin{array}{c}0 \\
\text { (0) }\end{array}$ & $\begin{array}{c}0 \\
\text { (0) }\end{array}$ & $478(9.9)$ \\
\hline & 2 & $\begin{array}{c}126 \\
(25.7)\end{array}$ & $\begin{array}{c}125 \\
(26.6)\end{array}$ & $\begin{array}{c}108 \\
(21.1)\end{array}$ & $\begin{array}{c}58 \\
(12.4)\end{array}$ & $\begin{array}{c}44 \\
(8.9)\end{array}$ & $\begin{array}{c}22 \\
(4.6)\end{array}$ & $8(1.7)$ & $2(0.4)$ & $\begin{array}{c}0 \\
\text { (0) }\end{array}$ & $\begin{array}{c}0 \\
\text { (0) }\end{array}$ & $\begin{array}{c}493 \\
(10.2)\end{array}$ \\
\hline & 3 & $\begin{array}{c}50 \\
(10.2)\end{array}$ & $\begin{array}{c}105 \\
(22.3)\end{array}$ & $\begin{array}{c}114 \\
(22.2)\end{array}$ & $\begin{array}{c}82 \\
(17.6)\end{array}$ & $\begin{array}{c}58 \\
(11.8)\end{array}$ & $\begin{array}{c}46 \\
(9.6)\end{array}$ & $\begin{array}{c}23 \\
(4.9)\end{array}$ & $\begin{array}{c}5 \\
\text { (1) }\end{array}$ & $\begin{array}{l}0 \\
\text { (0) }\end{array}$ & $\begin{array}{c}0 \\
\text { (0) }\end{array}$ & $483(10)$ \\
\hline & 4 & $\begin{array}{c}36 \\
(7.3)\end{array}$ & $\begin{array}{c}55 \\
(11.7)\end{array}$ & $\begin{array}{c}101 \\
(19.7)\end{array}$ & $\begin{array}{c}86 \\
(18.4)\end{array}$ & $\begin{array}{c}92 \\
(18.7)\end{array}$ & $\begin{array}{c}61 \\
(12.8)\end{array}$ & $\begin{array}{l}37 \\
(7.8)\end{array}$ & $\begin{array}{c}22 \\
(4.5)\end{array}$ & $4(0.8)$ & $\begin{array}{c}0 \\
\text { (0) }\end{array}$ & $\begin{array}{c}494 \\
(10.2)\end{array}$ \\
\hline & 5 & $\begin{array}{c}16 \\
(3.3)\end{array}$ & $\begin{array}{c}42 \\
(8.9)\end{array}$ & $\begin{array}{c}48 \\
(9.4)\end{array}$ & $\begin{array}{c}88 \\
(18.8)\end{array}$ & $\begin{array}{c}88 \\
(17.9)\end{array}$ & $\begin{array}{c}84 \\
(17.6)\end{array}$ & $71(15)$ & $\begin{array}{c}51 \\
(10.4)\end{array}$ & $8(1.6)$ & $\begin{array}{c}0 \\
\text { (0) }\end{array}$ & $\begin{array}{c}496 \\
(10.2)\end{array}$ \\
\hline & 6 & $4(0.8)$ & $\begin{array}{c}20 \\
(4.3)\end{array}$ & $\begin{array}{c}50 \\
(9.7)\end{array}$ & $\begin{array}{c}73 \\
(15.6)\end{array}$ & $\begin{array}{c}70 \\
(14.2)\end{array}$ & $\begin{array}{c}78 \\
(16.3)\end{array}$ & $\begin{array}{c}84 \\
(17.7)\end{array}$ & $\begin{array}{c}75 \\
(15.2)\end{array}$ & $\begin{array}{c}20 \\
(4.1)\end{array}$ & $3(0.6)$ & $477(9.8)$ \\
\hline & 7 & $1(0.2)$ & $7(1.5)$ & $\begin{array}{c}22 \\
(4.3)\end{array}$ & $\begin{array}{c}34 \\
(7.3)\end{array}$ & $\begin{array}{c}76 \\
(15.4)\end{array}$ & $91(19)$ & $\begin{array}{c}83 \\
(17.5)\end{array}$ & $\begin{array}{c}96 \\
(19.5)\end{array}$ & $\begin{array}{c}64 \\
(13.1)\end{array}$ & $\begin{array}{c}12 \\
(2.5)\end{array}$ & $486(10)$ \\
\hline & 8 & $\begin{array}{c}0 \\
\text { (0) }\end{array}$ & $1(0.2)$ & $\begin{array}{c}10 \\
(1.9)\end{array}$ & $\begin{array}{c}19 \\
(4.1)\end{array}$ & $\begin{array}{c}33 \\
(6.7)\end{array}$ & $\begin{array}{c}63 \\
(13.2)\end{array}$ & $\begin{array}{c}102 \\
(21.5)\end{array}$ & $\begin{array}{c}102 \\
(20.7)\end{array}$ & $\begin{array}{c}110 \\
(22.6)\end{array}$ & $\begin{array}{c}25 \\
(5.2)\end{array}$ & $465(9.6)$ \\
\hline & 9 & $\begin{array}{c}0 \\
\text { (0) }\end{array}$ & $\begin{array}{l}0 \\
\text { (0) }\end{array}$ & $\begin{array}{l}0 \\
\text { (0) }\end{array}$ & $6(1.3)$ & $\begin{array}{c}12 \\
(2.4)\end{array}$ & $\begin{array}{c}20 \\
(4.2)\end{array}$ & $\begin{array}{c}53 \\
(11.2)\end{array}$ & $\begin{array}{c}103 \\
(20.9)\end{array}$ & $\begin{array}{c}165 \\
(33.9)\end{array}$ & $\begin{array}{c}141 \\
(29.1)\end{array}$ & $\begin{array}{c}500 \\
(10.3)\end{array}$ \\
\hline & 10 & $\begin{array}{l}0 \\
\text { (0) }\end{array}$ & $\begin{array}{l}0 \\
\text { (0) }\end{array}$ & $1(0.2)$ & $1(0.2)$ & $1(0.2)$ & $\begin{array}{c}5 \\
\text { (1) }\end{array}$ & $\begin{array}{c}13 \\
(2.7)\end{array}$ & $\begin{array}{c}36 \\
(7.3)\end{array}$ & $\begin{array}{c}116 \\
(23.8)\end{array}$ & $\begin{array}{c}303 \\
(62.6)\end{array}$ & $476(9.8)$ \\
\hline & & $\begin{array}{c}491 \\
(10.1)\end{array}$ & $\begin{array}{c}470 \\
(9.7)\end{array}$ & $\begin{array}{c}513 \\
(10.6)\end{array}$ & $\begin{array}{c}467 \\
(9.6)\end{array}$ & $\begin{array}{c}492 \\
(10.1)\end{array}$ & $\begin{array}{l}478 \\
(9.9)\end{array}$ & $\begin{array}{l}474 \\
(9.8)\end{array}$ & $\begin{array}{c}492 \\
(10.1)\end{array}$ & $\begin{array}{l}487 \\
(10)\end{array}$ & $\begin{array}{l}484 \\
(10)\end{array}$ & $\begin{array}{l}4848 \\
(100)\end{array}$ \\
\hline
\end{tabular}

Tablo 3'te matematik ve problem çözme puanları \%10'luk kategorilere göre dağılımları bulunmaktadır. Kategorilerdeki birey sayıları ve parantez içerisinde de bu sayıların ilgili sütundaki toplam birey sayısı içerisindeki yüzdesi bu tabloda sunulmuştur. Bu yüzdeler, matematik puanı açısından ilgili kategoride yer alan bireylerin yüzde kaçının problem çözme becerisinde de aynı kategoride yer aldığını göstermektedir. Bu sayılar incelendiğinde, alt ve üst kategorilerde uyum daha fazlayken ortadaki kategorilerde uyumun daha düşük olduğu görülmektedir. Hem problem çözme hem de matematik puanlarına göre aynı kategoride olan bireyler incelendiğinde birinci kategori için \%52.5, ikinci kategori için \%26.6, üçüncü kategori için \%22.2, dördüncü kategori için $\% 18.4$, beşinci kategori için \%17.9, altıncı kategori için \%16.3, yedinci kategori için \%17.5, sekizinci kategori için \%20.7, dokuzuncu kategori için \%33.9 ve onuncu kategori için \%62.6 olduğu söylenebilir. Genel uyum tüm kategorilerdeki uyumlu bireylerin yüzdesi olarak değerlendirildiğinde \%29 olduğu söylenebilir. Beklenti tablosu olasılık anlamı da taşıdığından örneğin problem çözme puanı açısından 7. kategoride bulunan bir bireyin matematik puanı açısından 7. kategoride olma olasılığı \%17.07'dir (83/486=0.1707). Benzer şekilde düşünüldüğünde 8 . kategoride olma olasılığı ise \%19.75'tir (96/486=0.1975). Tablo 3'e göre oluşturulan damlacık grafiği Şekil 3'te sunulmuştur. 


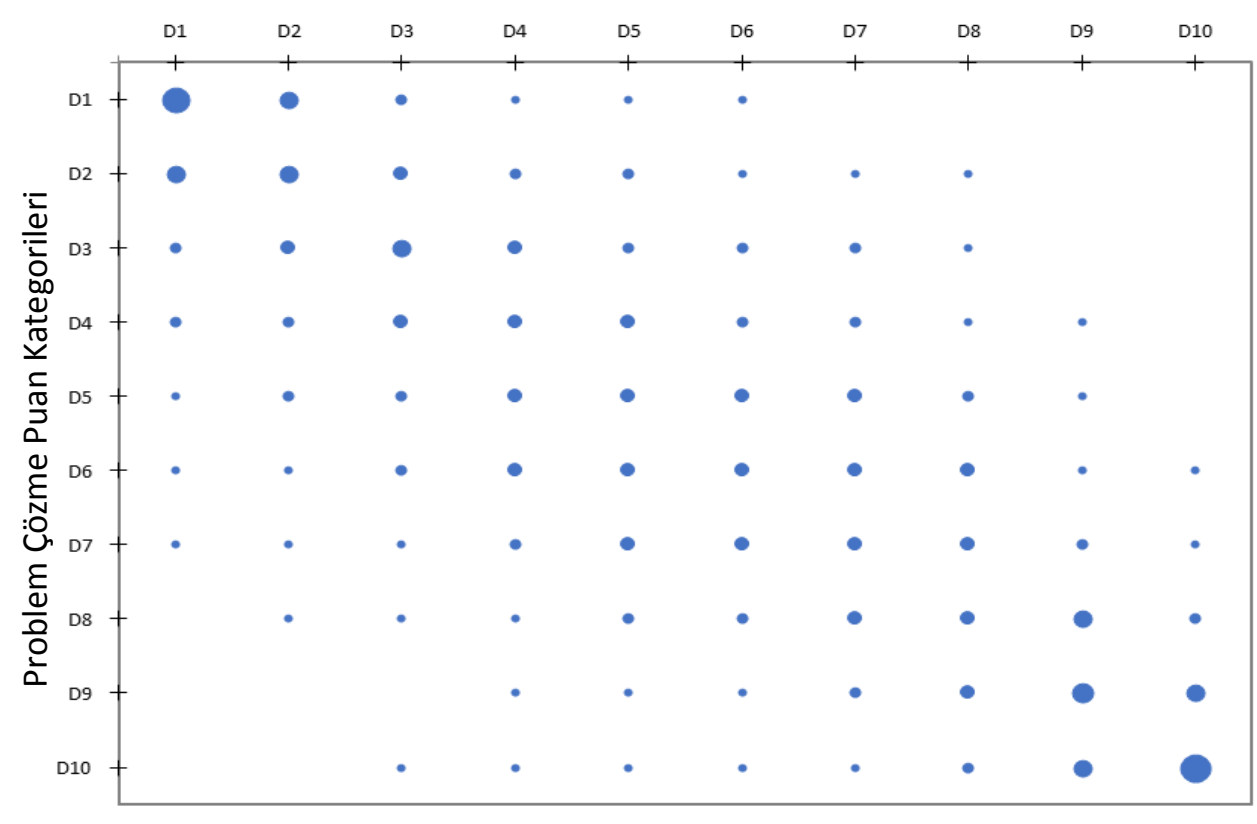

Matematik Puan Kategorileri

Şekil 3. PISA 2012 Matematik ve Problem Çözme Puanları \%10’luk Dilim Karşılaştırılması

Şekil 3 incelendiğinde uç kategorilerdeki puanların daha fazla uyum içinde olduğu ancak orta kategorilerin daha az uyum içinde olduğu görülmektedir. Damlacık grafiğinde damlacıkların boyutu büyüdükçe aynı kategorideki birey sayısının daha fazla olduğu anlamına gelmektedir. Buna göre damlacıklar incelendiğinde problem çözme becerisi açısından 8. kategoride olan bireyin matematik puanı açısından 9. kategoride olma olasılığının daha yüksek olduğu söylenebilir. Çünkü belirtilen yerdeki damlacık her iki alanda da 8. kategoride olan bireylerden daha büyüktür. Bireylerin \%10'luk puan dilimine göre matematik ve problem çözme puanları arasındaki uyumun belirlenmesine yönelik yürütülen uyum analizi sonucunda değişken kategorilerinin düzlemde gösterimi Şekil 4'te sunulmuştur. 


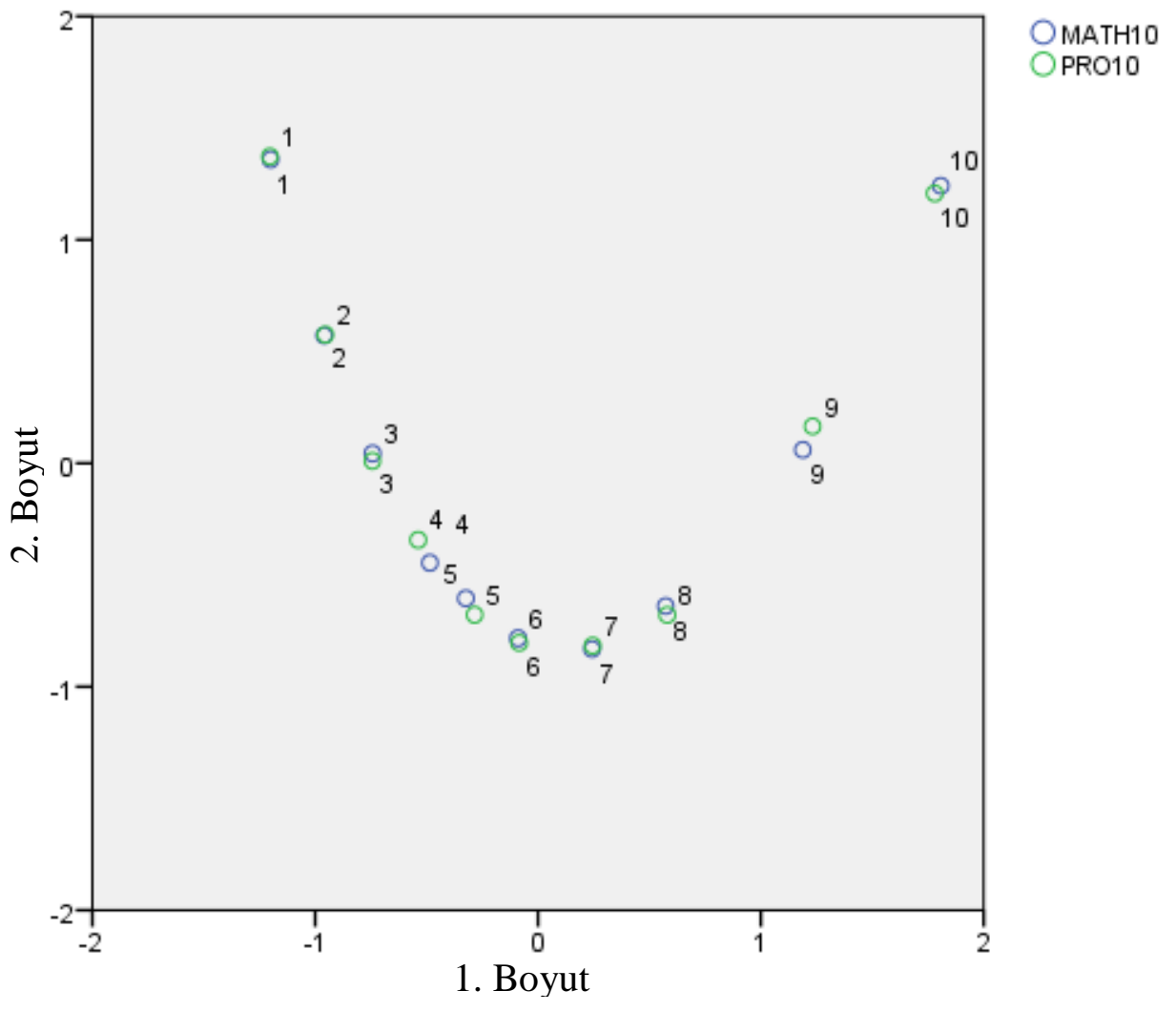

Şekil 4. PISA 2012 Matematik Ve Problem Çözme Puanları \%10’luk Puan Dilimine Göre Değişken Kategorilerinin Düzlemde Gösterimi

Şekil 4 incelendiğinde uyum analizi sonucunda ortadaki kategorilerdeki bireylerde uyumun azaldığı görülmektedir. 4., 5. ve 9. kategorilerin uyumunun diğer kategorilere göre daha az olduğu söylenebilir.

3.2 Matematik ve problem çözme puanlarının \%20'lik dilimler halinde beş gruba ayrılarak incelenmesi

PISA 2003 değerlendirmelerinden elde edilen matematik ve problem çözme puanları 20'lik dilimler halinde beş gruba ayrılmış ve bireylerin eşleşme sayıları ile eşleşme yüzdeleri beklenti tablosu olarak Tablo 4'te sunulmuştur. 
Abdullah Faruk KILIÇ | Başak ERDEM KARA | Nuri DOĞAN

Tablo 4. PISA 2003 Matematik ve Problem Çözme Puanları \%20'lik Kategorilere Göre Dağılımı

\begin{tabular}{|c|c|c|c|c|c|c|c|}
\hline \multirow{2}{*}{\multicolumn{2}{|c|}{ Kategoriler }} & \multicolumn{5}{|c|}{ Matematik Puan Kategorileri } & \multirow{2}{*}{ Toplam } \\
\hline & & 1 & 2 & 3 & 4 & 5 & \\
\hline \multirow{10}{*}{ 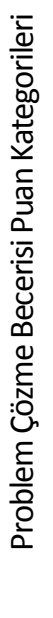 } & \multirow{2}{*}{1} & 663 & 248 & 63 & 8 & 0 & 982 \\
\hline & & $(68.8)$ & (25.6) & (6.5) & $(0.8)$ & (0) & $(20.2)$ \\
\hline & \multirow{2}{*}{2} & 235 & 400 & 271 & 55 & 3 & 964 \\
\hline & & (24.4) & (41.4) & (28) & $(5.6)$ & $(0.3)$ & (19.9) \\
\hline & \multirow{2}{*}{3} & 61 & 240 & 361 & 266 & 34 & 962 \\
\hline & & (6.3) & $(24.8)$ & (37.3) & $(27)$ & $(3.5)$ & $(19.8)$ \\
\hline & \multirow{2}{*}{4} & 5 & 76 & 247 & 462 & 194 & 984 \\
\hline & & $(0.5)$ & (7.9) & $(25.5)$ & (46.9) & $(20)$ & $(20.3)$ \\
\hline & \multirow{2}{*}{5} & 0 & 3 & 27 & 194 & 739 & 963 \\
\hline & & (0) & $(0.3)$ & (2.8) & (19.7) & $(76.2)$ & (19.8) \\
\hline \multirow{2}{*}{\multicolumn{2}{|c|}{ Toplam }} & 964 & 967 & 969 & 985 & 970 & 4855 \\
\hline & & (19.9) & (19.9) & (20) & (20.3) & (20) & (100) \\
\hline
\end{tabular}

Tablo 4'te matematik ve problem çözme puanları \%20'lik kategorilere göre dağılımları bulunmaktadır. İlgili tabloda, kategorilerdeki birey sayıları ve parantez içerisinde ise bu sayıların sütunlardaki toplam birey sayısı içindeki yüzdesi verilmiştir. Böylece matematik puan kategorilerindeki bireylerin, problem çözme kategorilerine nasıl dağıldığı incelenmiştir. Tablodaki verilere göre alt ve üst kategorilerde uyumun daha fazla, ortalarda daha az olduğu söylenebilir. Hem problem çözme hem de matematik puanlarına göre aynı kategoride olan bireyler incelendiğinde birinci kategori için \%68.8, ikinci kategori için \%41.4, üçüncü kategori için \%37.3, dördüncü kategori için \%46.9 ve beşinci kategori için \%76.2 olduğu söylenebilir. Ayrıca problem çözme ve matematik puanları açısından yüzde olarak bakıldığında 4. ve 5 . Kategori kesişimlerinde bulunan bireylerin yüzdesinin daha fazla olduğu söylenebilir. Genel uyum tüm kategorilerdeki uyumlu bireylerin yüzdesi olarak değerlendirildiğinde \%54 olduğu söylenebilir. Beklenti tablosu olasılık anlamı da taşıdığından örneğin problem çözme puanı açısından 4. kategoride bulunan bir bireyin matematik puanı açısından 4. kategoride olma olasılı̆̆ \%46.95'tir (462/984=0.4695). Benzer şekilde düşünüldügünde 5. kategoride olma olasilığı ise \%19.71'dir (194/984=0.1971). Tablo 4'e göre oluşturulan damlacık grafiği Şekil 5'te sunulmuştur. 


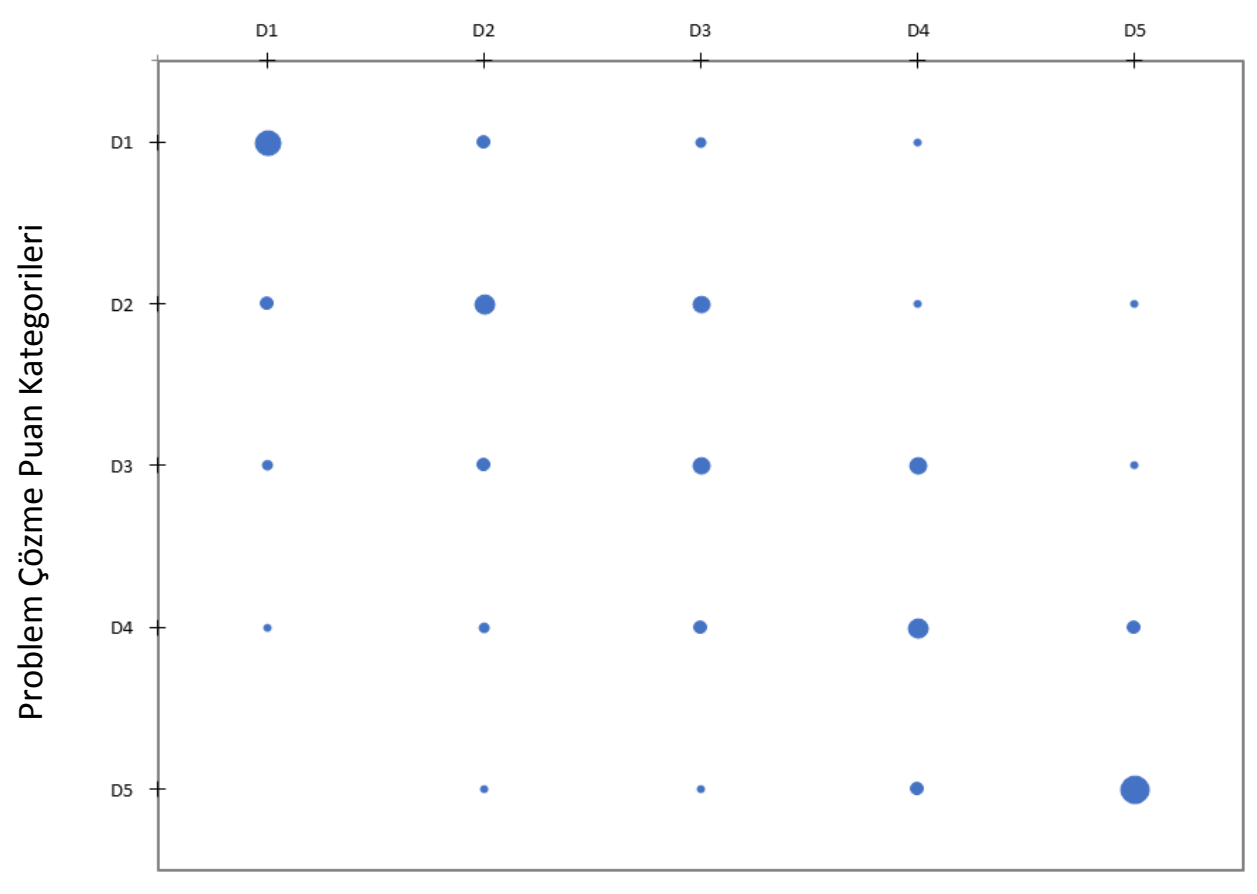

\section{Matematik Puan Kategorileri}

Şekil 5. PISA 2003 Matematik ve Problem Çözme Puanları \%20'lik Dilim Karşılaştırılması

Şekil 5 incelendiğinde üst uç kısımda bulunan kategorilerin daha fazla uyum içinde olduğu söylenebilir. Damlacık grafiğinde damlacıkların boyutu büyüdükçe aynı kategorideki birey sayısının daha fazla olduğu anlamına gelmektedir. Buna göre damlacıklar incelendiğinde köşegendeki elemanların diğerlerine göre daha büyük olduğu görülmektedir. Buna göre aynı karşılaştırma \%10'luk dilimde yapıldığında uyumun daha az olduğu ancak dilimlerin büyümesi halinde uyumun daha fazla olduğu söylenebilir. Bireylerin \%20'lik puan dilimine göre matematik ve problem çözme puanları arasındaki uyumun belirlenmesine yönelik yürütülen uyum analizi sonucunda değişken kategorilerinin düzlemde gösterimi Şekil 6 'da sunulmuştur. 


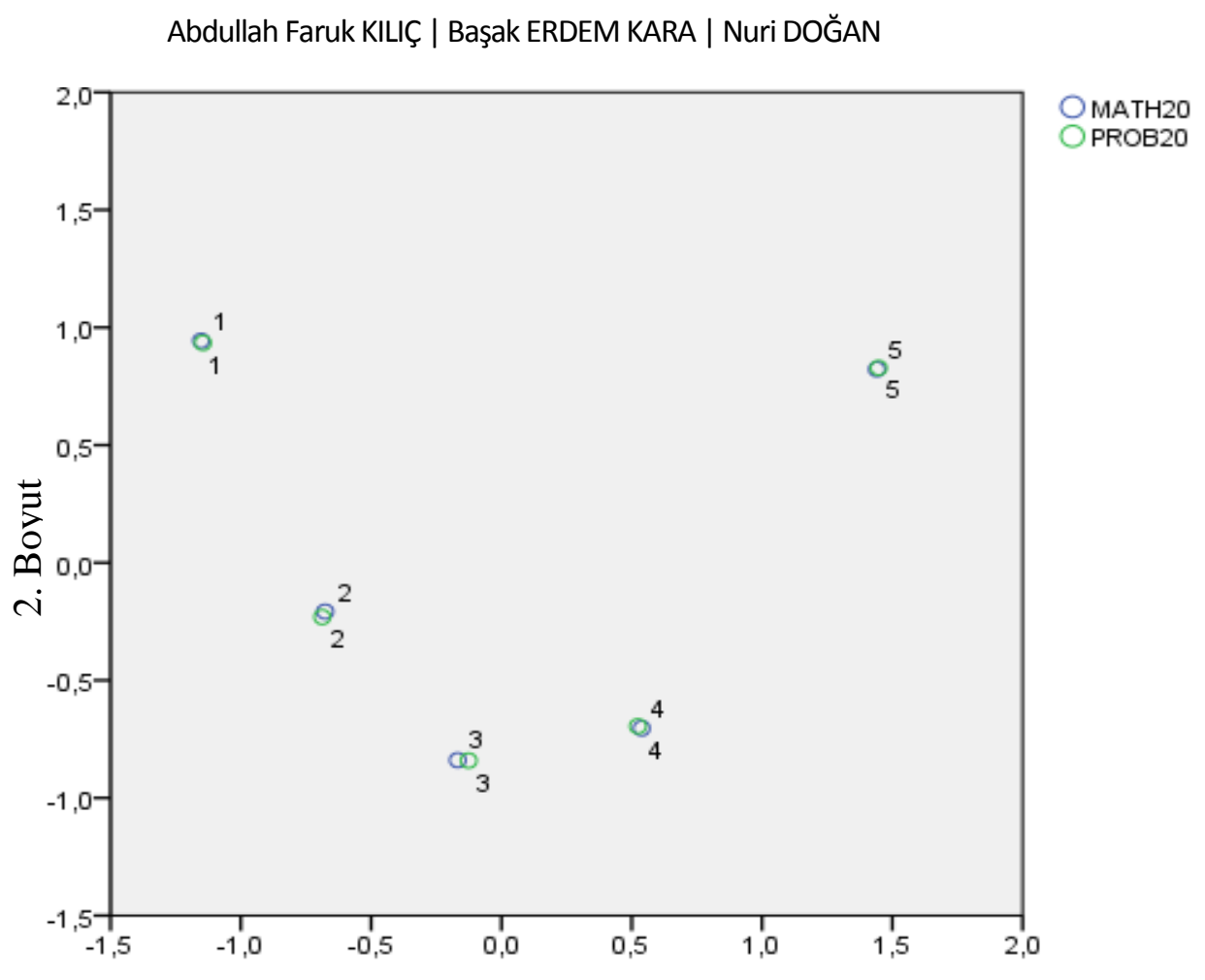

1. Boyut

Şekil 6. PISA 2003 matematik ve problem çözme puanları \%20'lik puan dilimine göre değişken kategorilerinin düzlemde gösterimi

Şekil 6 incelendiğinde uyum analizi sonucunda uçlardaki kategorilerde uyumun çok iyi olduğu ortada bulunan 3. kategorinin uyumunun nispeten daha az olduğu söylenebilir. PISA 2012 değerlendirmelerinden elde edilen matematik ve problem çözme puanları \%20'lik dilimler halinde beş gruba ayrımış ve bireylerin eşleşme sayıları ile eşleşme yüzdeleri beklenti tablosu olarak Tablo 5'te sunulmuştur. 
Tablo 5. PISA 2012 Matematik ve Problem Çözme Puanları \%20'lik Kategorilere Göre Dağılımı

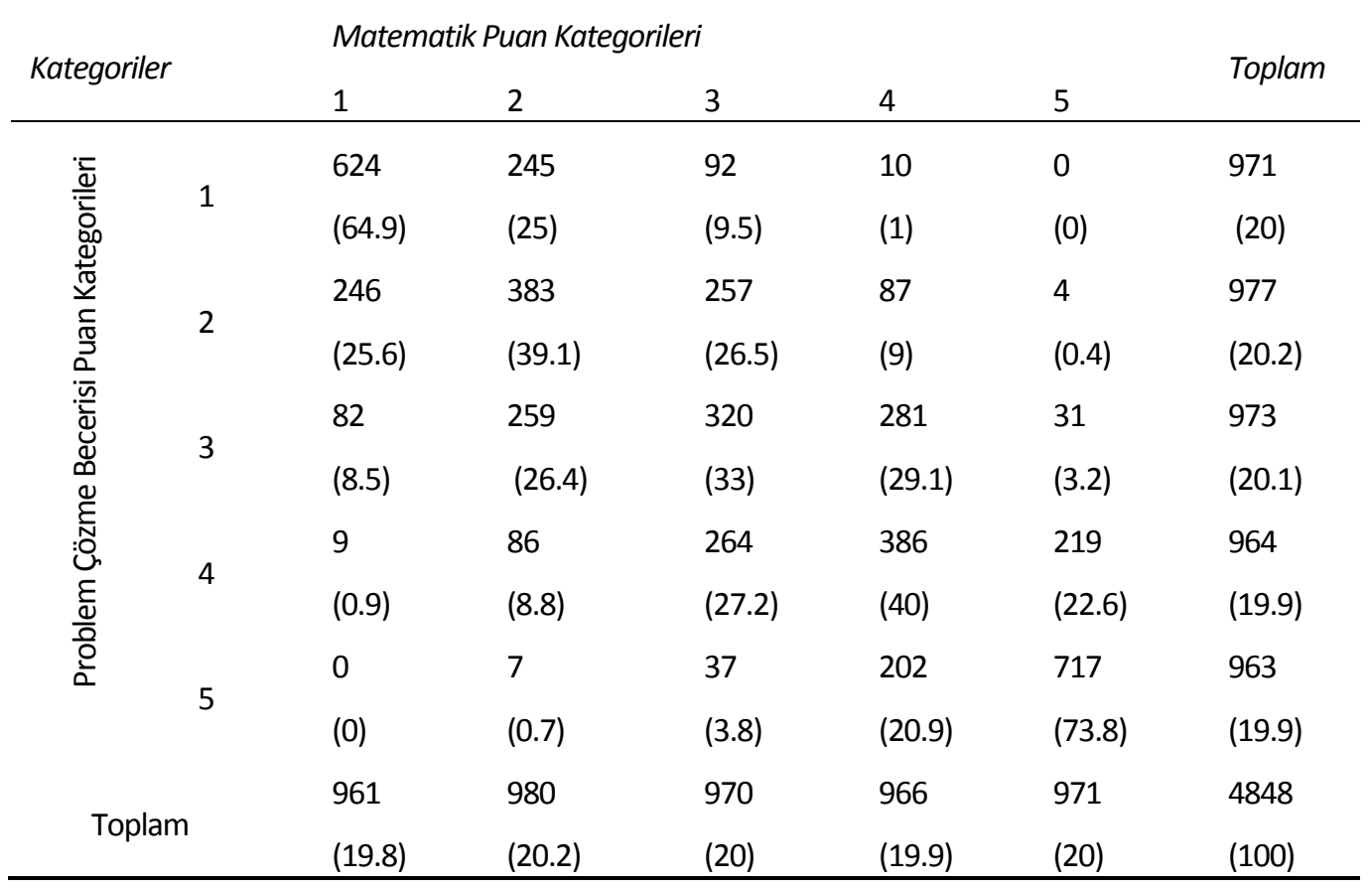

Tablo 5'te matematik ve problem çözme puanları \%20'lik kategorilere göre dağılımları bulunmaktadır. Bu tabloda, her bir kategorideki birey sayısı ve parantez içerisinde ise bu sayının ilgili sütundaki toplam birey sayısı içerisindeki yüzdesi verilmiştir. Böylece matematik puan kategorilerindeki bireylerin yüzde kaçının problem çözme becerisi kategorilerinde yer aldığı incelenmiştir. Incelemeler sonucunda, alt ve üst kategorilerde uyumun daha fazla olduğu görülmüştür. Hem problem çözme hem de matematik puanlarına göre aynı kategoride olan bireyler incelendiğinde birinci kategori için \%64.9, ikinci kategori için \%39,1, üçüncü kategori için \%33, dördüncü kategori için $\% 40$ ve beşinci kategori için $\% 73.8$ olduğu söylenebilir. Genel uyum tüm kategorilerdeki uyumlu bireylerin yüzdesi olarak değerlendirildiğinde $\% 50.2$ olduğu söylenebilir. Beklenti tablosu olasılık anlamı da taşıdığından örneğin problem çözme puanı açısından 4. kategoride bulunan bir bireyin matematik puanı açısından 4. kategoride olma olasılığı \%40.04'tür (386/964=0.4004). Benzer şekilde düşünüldügünde 5. kategoride olma olasılığı ise \%22.71'dir (219/964=0.2271). Tablo 5'e göre oluşturulan damlacık grafiği Şekil 7'de sunulmuştur. 


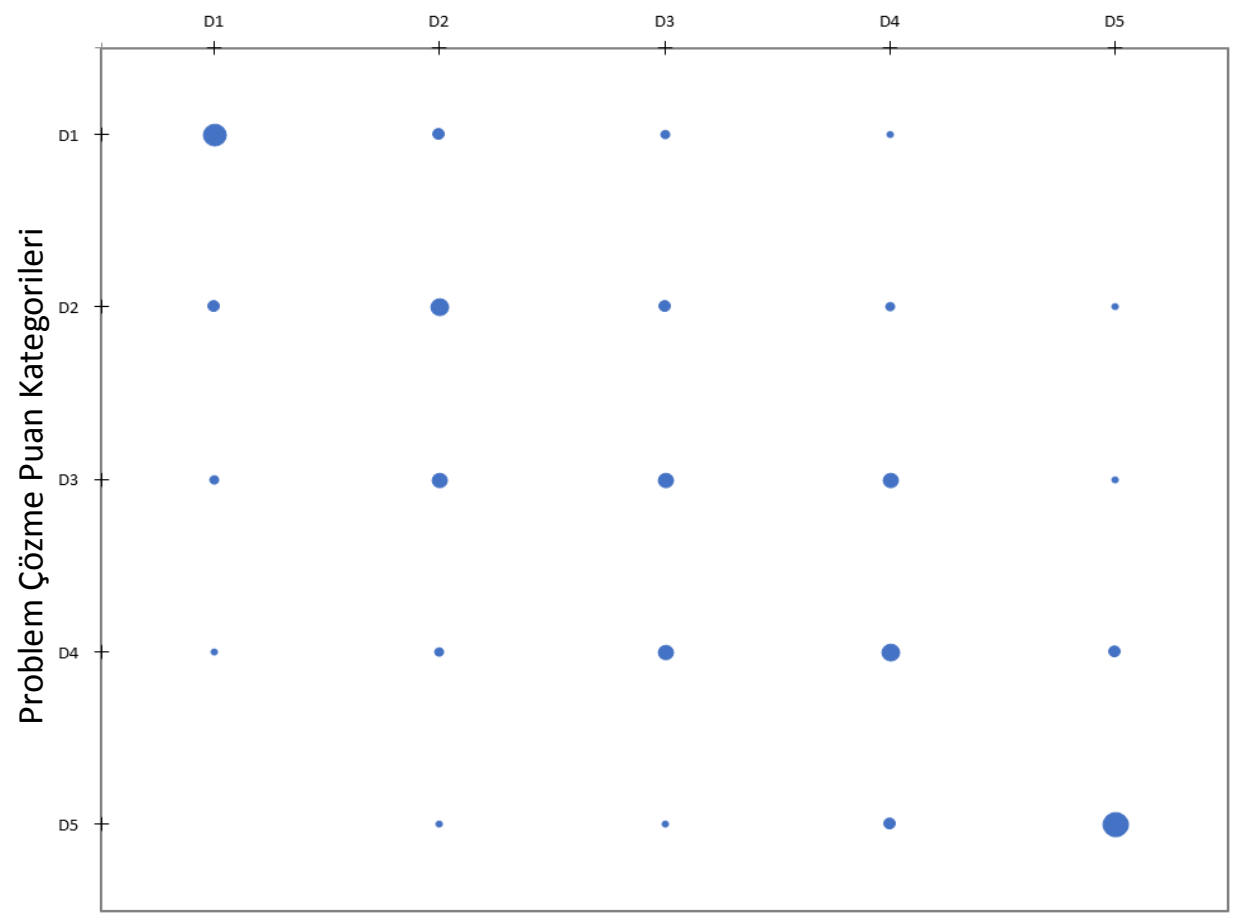

Matematik Puan Kategorileri

Şekil 7. PISA 2012 matematik ve problem çözme puanları \%20'lik dilimine göre karşılaştırıması

Şekil 7 incelendiğinde üst uç kısımda bulunan kategorilerle alt kısımda bulunanların benzer olduğu görülmektedir. Damlacık grafiğinde damlacıkların boyutu büyüdükçe aynı kategorideki birey sayısının daha fazla olduğu anlamına gelmektedir. Buna göre damlacıklar incelendiğinde köşegendeki elemanların diğerlerine göre daha büyük olduğu görülmektedir. Buna göre aynı karşılaştırma \%10'luk dilimde yapıldığında uyumun daha az olduğu ancak dilimlerin büyümesi halinde uyumun daha fazla olduğu söylenebilir. Bireylerin \%20'lik puan dilimine göre matematik ve problem çözme puanları arasındaki uyumun belirlenmesine yönelik yürütülen uyum analizi sonucunda değişken kategorilerinin düzlemde gösterimi Şekil 8'de sunulmuştur. 


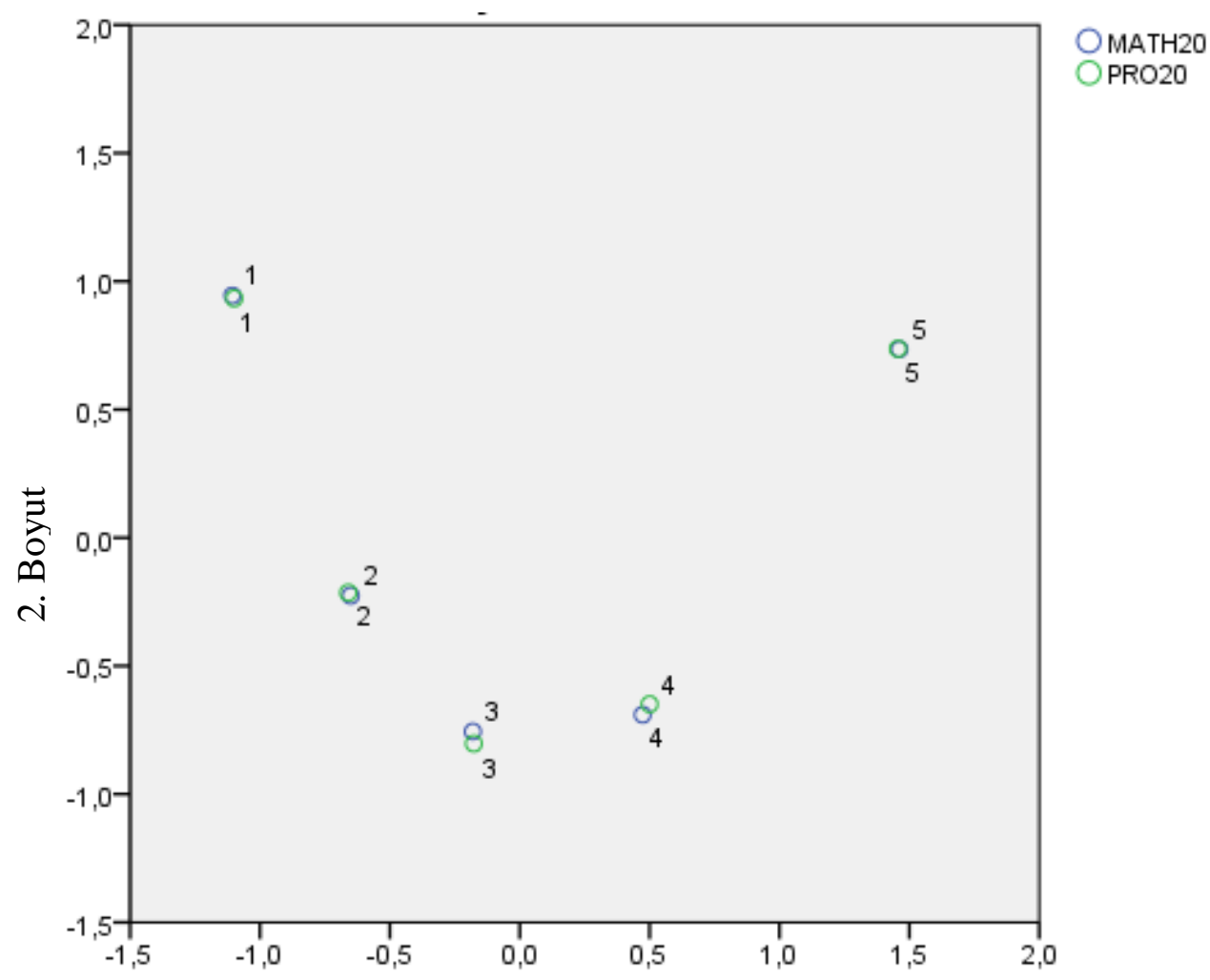

1. Boyut

Şekil 8. PISA 2012 Matematik ve Problem Çözme Puanları \%20'lik Puan Dilimine Göre Değişken Kategorilerinin Düzlemde Gösterimi

Şekil 8 incelendiğinde uyum analizi sonucunda 3. ve 4. Kategorilerin uyumlarının nispeten daha az olduğu, diğer kategori uyumlarının ise odlukça iyi olduğu söylenebilir.

\subsection{Matematik ve problem çözme puanlarının PISA puan kategorilerine göre incelenmesi}

PISA 2003 değerlendirmelerinden elde edilen matematik ve problem çözme puanları PISA puan kategorilerine göre 7 gruba ayrılmış ve bireylerin eşleşme sayıları ile eşleşme yüzdeleri beklenti tablosu olarak Tablo 6'da sunulmuştur. 
Tablo 6. PISA 2003 Matematik ve Problem Çözme Puanları PISA Kategorilere Göre Dağılımı

\begin{tabular}{|c|c|c|c|c|c|c|c|c|c|}
\hline \multirow{2}{*}{\multicolumn{2}{|c|}{ Kategoriler }} & \multicolumn{7}{|c|}{ Matematik Puan Kategorileri } & \multirow{2}{*}{ Toplam } \\
\hline & & 1 & 2 & 3 & 4 & 5 & 6 & 7 & \\
\hline \multirow{7}{*}{ 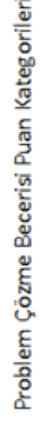 } & 1 & $\begin{array}{c}1173 \\
(48.9)\end{array}$ & $\begin{array}{c}34 \\
(4.3)\end{array}$ & $\begin{array}{c}11 \\
(1.7)\end{array}$ & $\begin{array}{c}0 \\
\text { (0) }\end{array}$ & $\begin{array}{c}0 \\
(0)\end{array}$ & $\begin{array}{l}0 \\
\text { (0) }\end{array}$ & $\begin{array}{c}0 \\
\text { (0) }\end{array}$ & $1218(25.1)$ \\
\hline & 2 & $\begin{array}{c}870 \\
(36.2)\end{array}$ & $\begin{array}{c}252 \\
(31.7)\end{array}$ & $\begin{array}{c}102 \\
(16.1)\end{array}$ & $\begin{array}{c}8 \\
(1.8)\end{array}$ & $\begin{array}{c}1 \\
(0.4)\end{array}$ & $\begin{array}{l}0 \\
\text { (0) }\end{array}$ & $\begin{array}{l}0 \\
\text { (0) }\end{array}$ & $1233(25.4)$ \\
\hline & 3 & $\begin{array}{c}314 \\
(13.1)\end{array}$ & $\begin{array}{c}370 \\
(46.6)\end{array}$ & $\begin{array}{c}280 \\
(44.1)\end{array}$ & $\begin{array}{c}107 \\
(23.7)\end{array}$ & $\begin{array}{c}14 \\
(5.2)\end{array}$ & $\begin{array}{c}3 \\
(2.1)\end{array}$ & $\begin{array}{c}0 \\
(0)\end{array}$ & $1088(22.4)$ \\
\hline & 4 & $\begin{array}{c}41 \\
(1.7)\end{array}$ & $\begin{array}{c}129 \\
(16.2)\end{array}$ & $\begin{array}{c}205 \\
(32.3)\end{array}$ & $\begin{array}{c}224 \\
(49.7)\end{array}$ & $\begin{array}{c}108 \\
(40.3)\end{array}$ & $\begin{array}{c}21 \\
(14.8)\end{array}$ & $\begin{array}{c}4 \\
(2.4)\end{array}$ & $\begin{array}{c}732 \\
(15.1)\end{array}$ \\
\hline & 5 & $\begin{array}{c}3 \\
(0.1)\end{array}$ & $\begin{array}{c}9 \\
(1.1)\end{array}$ & $\begin{array}{c}35 \\
(5.5)\end{array}$ & 98 (21.7) & $\begin{array}{c}111 \\
(41.4)\end{array}$ & $\begin{array}{c}66 \\
(46.5)\end{array}$ & $\begin{array}{c}14 \\
(8.5)\end{array}$ & $\begin{array}{c}336 \\
(6.9)\end{array}$ \\
\hline & 6 & $\begin{array}{c}0 \\
\text { (0) }\end{array}$ & $\begin{array}{c}0 \\
\text { (0) }\end{array}$ & $\begin{array}{c}2 \\
(0.3)\end{array}$ & $\begin{array}{c}14 \\
(3.1)\end{array}$ & 31 (11.6) & $\begin{array}{c}40 \\
(28.2)\end{array}$ & $\begin{array}{c}49 \\
(29.9)\end{array}$ & $\begin{array}{l}136 \\
(2.8)\end{array}$ \\
\hline & 7 & $\begin{array}{c}0 \\
(0)\end{array}$ & $\begin{array}{c}0 \\
(0)\end{array}$ & $\begin{array}{c}0 \\
(0)\end{array}$ & $\begin{array}{c}0 \\
(0)\end{array}$ & $\begin{array}{c}3 \\
(1.1)\end{array}$ & $\begin{array}{c}12 \\
(8.5)\end{array}$ & $\begin{array}{c}97 \\
(59.1)\end{array}$ & $\begin{array}{c}112 \\
(2.3)\end{array}$ \\
\hline \multicolumn{2}{|c|}{ Toplam } & $\begin{array}{c}2401 \\
(49.5) \\
\end{array}$ & $\begin{array}{r}794 \\
(16.4) \\
\end{array}$ & $\begin{array}{r}635 \\
(13.1) \\
\end{array}$ & 451 (9.3) & $268(5.5)$ & $142 \quad(2.9)$ & $\begin{array}{l}164 \\
(3.4)\end{array}$ & $\begin{array}{l}4855 \\
(100)\end{array}$ \\
\hline
\end{tabular}

Tablo 6'da matematik ve problem çözme puanları PISA kategorilere göre dağılımları bulunmaktadır. Tablo 6'da kategorilerdeki birey sayıları ve parantez içinde de bu sayıların toplam $(\mathrm{N}=4855)$ birey sayısı içindeki yüzdesi verilmiştir. Buna göre üst kategorilerde uyumun daha fazla olduğu söylenebilir. Ancak üst kategorilerdeki birey sayısının alt kategorilere göre oldukça az olduğu dikkat çekmektedir. Örneğin problem çözme becerisi açısından 2. Kategoride olan 1233 kişi varken 7. kategoride 112 kişi bulunmaktadır. Hem problem çözme hem de matematik puanlarına göre aynı kategoride olan bireyler incelendiğinde birinci kategori için \%48.9, ikinci kategori için \%31.7, üçüncü kategori için \%44.1, dördüncü kategori için \%49.7, beşinci kategori için \%41.4, altıncı kategori için \%28.2 ve yedinci kategori için \%59.1 olduğu söylenebilir. Genel uyum tüm kategorilerdeki uyumlu bireylerin yüzdesi olarak değerlendirildiğinde \%44.9 olduğu söylenebilir. Beklenti tablosu olasılık anlamı da taşıdığından örneğin problem çözme puanı açısından 5. kategoride bulunan bir bireyin matematik puanı açısından 5. kategoride olma olasılı̆̆ı \%33.04'tür (111/336=0.3304). Benzer şekilde düşünüldüğünde 6 . kategoride olma olasılı̆̆ı ise \%19.64'tür (66/336=0.1964). Tablo 6'ya göre oluşturulan damlacık grafiği Şekil 9'da sunulmuştur. 


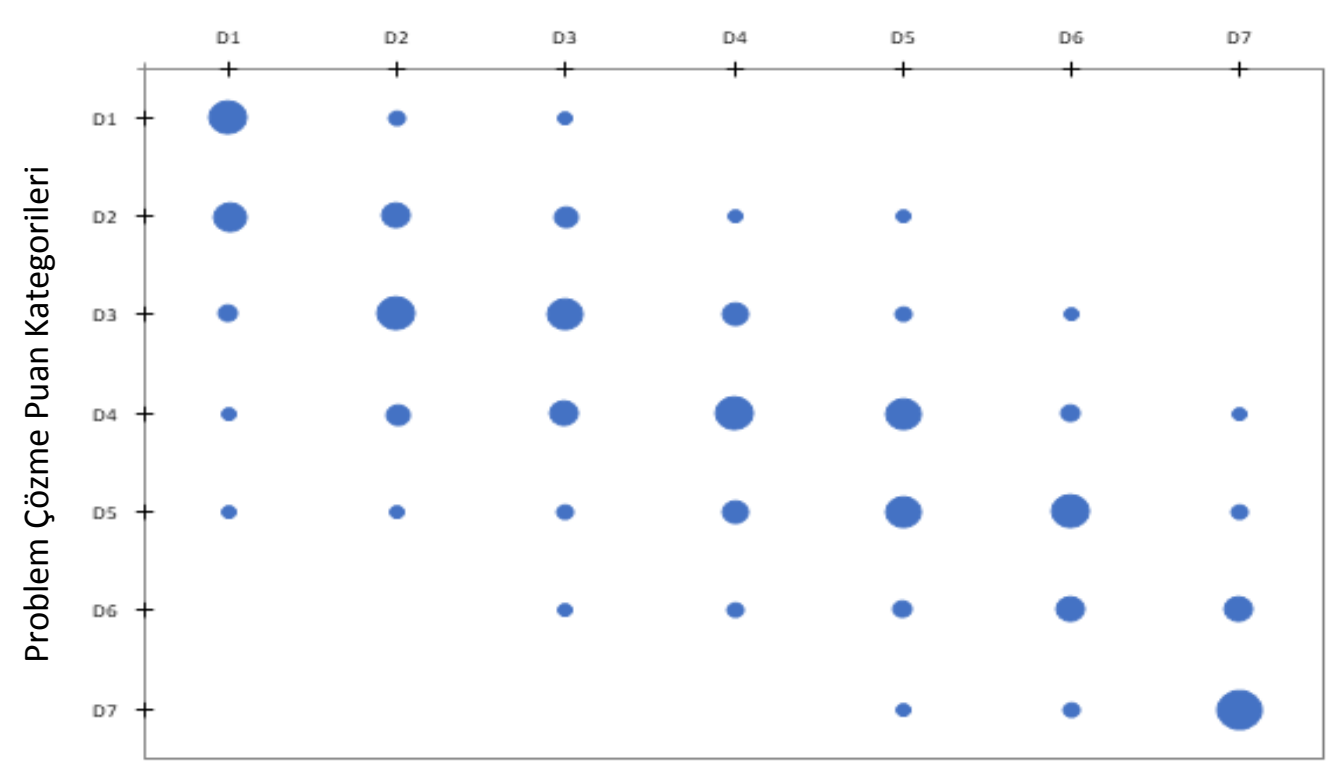

Matematik Puan Kategorileri

Şekil 9. PISA 2003 Matematik ve Problem Çözme Puanları PISA Kategorilerine Göre Karşılaştırilması

Şekil 9 incelendiğinde en yüksek uyumun üst uç kısımda görüldüğü, alt uçtaki uyumun da yüksek olduğu söylenebilir. Damlacıkların boyutunun büyüklüğü her iki alanda da aynı kategoride olan birey yüzdesinin fazlalığının göstergesidir. Buna göre damlacıklar incelendiğinde matematik puanı bakımından kategori 2'de olan öğrencinin problem çözmede kategori 3'te, kategori 6'da yer alan bireyin kategori 5 'te, yer alma olasılığının daha yüksek olduğu görülmüştür. Bireylerin PISA puan kategorilerine göre matematik ve problem çözme puanları arasındaki uyumun belirlenmesine yönelik yürütülen uyum analizi sonucunda değişken kategorilerinin düzlemde gösterimi Şekil $10^{\prime}$ da sunulmuştur. 


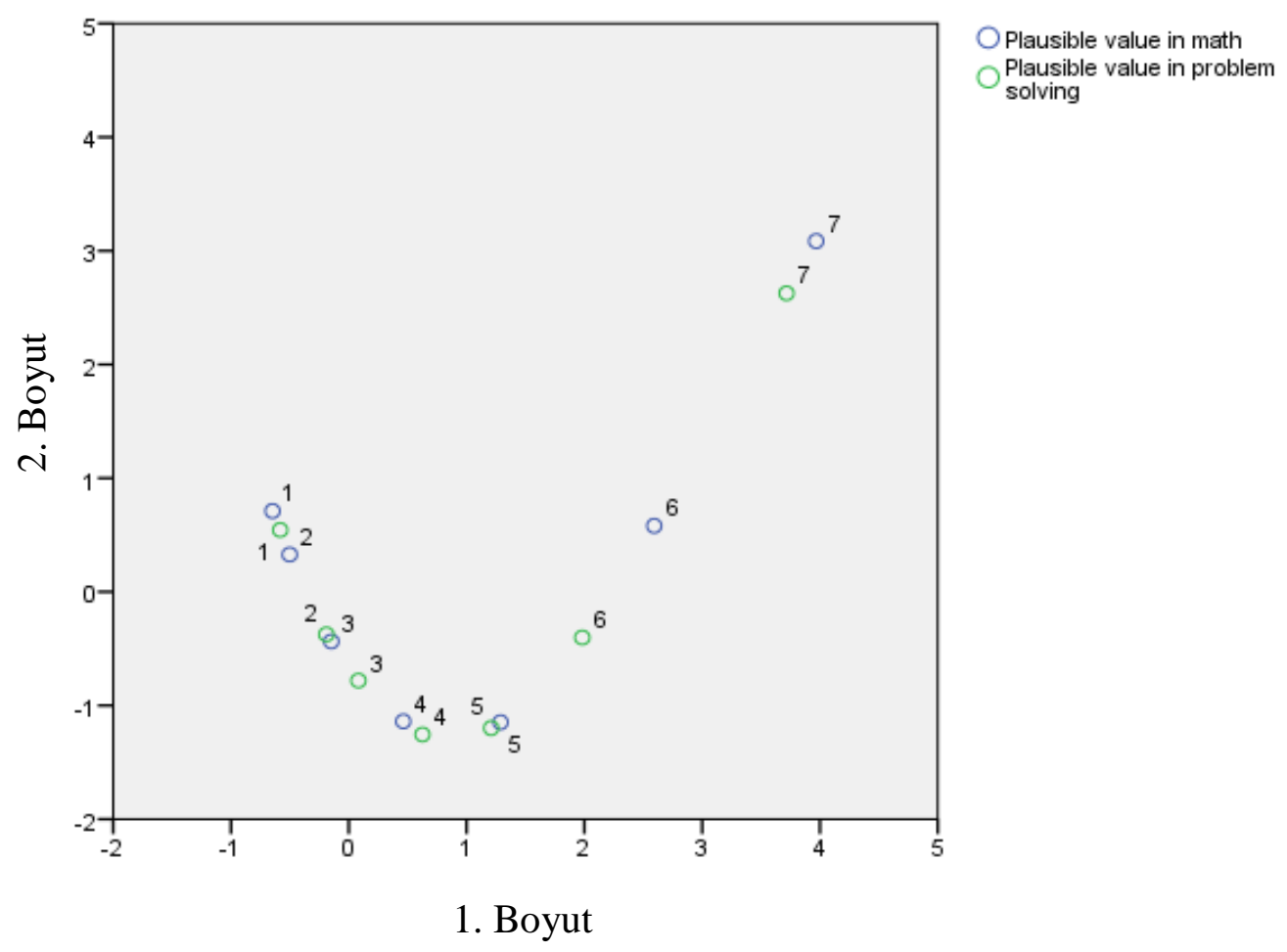

Şekil 10. PISA 2003 Matematik ve Problem Çözme Puanları PISA Kategorilerine Göre Değişken Kategorilerinin Düzlemde Gösterimi

Şekil 10 incelendiğinde uyum analizi sonucunda \%10'luk ve \%20'lil dilimlere nazaran uyumun daha az olduğu söylenebilir. Matematikte birinci ve ikinci düzeyde bulunan bireyler problem çözme açısından birinci düzeye karşılık gelmektedir. Matematiğin 3. Düzeyinde olan bireyler problem çözme açısından 2. Kategoriyle uyum sağlamıştır. Matematik ve problem çözme becerilerinin 6 . Kategorisi açısından birbiriyle uyumlu olmadığı söylenebilir. PISA 2012 değerlendirmelerinden elde edilen matematik ve problem çözme puanları PISA kategorilerine göre ayrılmış ve bireylerin eşleşme sayıları ile eşleşme yüzdeleri beklenti tablosu olarak Tablo 7'de sunulmuştur. 
Tablo 7. PISA 2012 Matematik ve Problem Çözme Puanları PISA Kategorilere Göre Dağılımı

\begin{tabular}{|c|c|c|c|c|c|c|c|c|c|}
\hline \multirow{2}{*}{\multicolumn{2}{|c|}{ Kategoriler }} & \multicolumn{7}{|c|}{ Matematik Puan Kategorileri } & \multirow{4}{*}{$\begin{array}{c}\text { Toplam } \\
770 \\
(15.9)\end{array}$} \\
\hline & & \multirow{3}{*}{$\begin{array}{c}1 \\
356 \\
(68.9)\end{array}$} & \multirow{2}{*}{$\begin{array}{c}\mathbf{2} \\
338 \\
(27.8)\end{array}$} & \multirow{2}{*}{$\begin{array}{c}3 \\
74 \\
(4.8)\end{array}$} & \multirow{3}{*}{$\begin{array}{c}4 \\
2 \\
(0.2)\end{array}$} & \multirow{3}{*}{$\begin{array}{c}5 \\
0 \\
(0)\end{array}$} & \multirow{3}{*}{$\begin{array}{c}6 \\
0 \\
(0)\end{array}$} & \multirow{3}{*}{$\begin{array}{c}7 \\
0 \\
(0)\end{array}$} & \\
\hline$\frac{\pi}{\frac{5}{2}}$ & 1 & & & & & & & & \\
\hline $\begin{array}{l}5 \\
0 \\
80 \\
0\end{array}$ & & & $\begin{array}{c}(27.8) \\
575\end{array}$ & $\begin{array}{c}(4.8) \\
471\end{array}$ & & & & & \\
\hline 泀 & 2 & $(25.9)$ & (47.3) & (30.7) & (6) & $(0.4)$ & (0) & (0) & $1241(25.6)$ \\
\hline ह & 3 & $\begin{array}{c}27 \\
(5.2)\end{array}$ & $\begin{array}{c}273 \\
(22.5)\end{array}$ & $\begin{array}{c}646 \\
(42.2)\end{array}$ & $\begin{array}{c}271 \\
(27.5)\end{array}$ & $\begin{array}{c}21 \\
(4.4)\end{array}$ & $\begin{array}{l}0 \\
\text { (0) }\end{array}$ & $\begin{array}{c}0 \\
\text { (0) }\end{array}$ & $1238(25.5)$ \\
\hline 产 & 4 & $\begin{array}{c}0 \\
\text { (0) }\end{array}$ & $\begin{array}{c}29 \\
(2.4)\end{array}$ & $\begin{array}{c}292 \\
(19.1)\end{array}$ & $\begin{array}{c}387 \\
(39.2)\end{array}$ & $\begin{array}{c}96 \\
(20)\end{array}$ & $\begin{array}{c}5 \\
(4.7)\end{array}$ & $\begin{array}{c}0 \\
\text { (0) }\end{array}$ & $\begin{array}{c}809 \\
(16.7)\end{array}$ \\
\hline $\begin{array}{l}\Phi \\
\text { हूँ }\end{array}$ & 5 & $\begin{array}{c}0 \\
\text { (0) }\end{array}$ & $\begin{array}{c}1 \\
(0.1)\end{array}$ & $\begin{array}{c}49 \\
(3.2)\end{array}$ & $\begin{array}{c}212 \\
(21.5)\end{array}$ & $\begin{array}{c}181 \\
(37.6)\end{array}$ & $\begin{array}{c}24 \\
(22.4)\end{array}$ & $\begin{array}{c}0 \\
\text { (0) }\end{array}$ & $\begin{array}{l}467 \\
(9.6)\end{array}$ \\
\hline है & 6 & $\begin{array}{c}0 \\
(0)\end{array}$ & $\begin{array}{l}0 \\
\text { (0) }\end{array}$ & $\begin{array}{c}0 \\
(0)\end{array}$ & $\begin{array}{c}52 \\
(5.3)\end{array}$ & $\begin{array}{l}149 \\
(31)\end{array}$ & $\begin{array}{c}39 \\
(36.4)\end{array}$ & $\begin{array}{c}2 \\
(22.2)\end{array}$ & $\begin{array}{l}242 \\
(5)\end{array}$ \\
\hline$\frac{0}{\circ}$ & 7 & $\begin{array}{c}0 \\
(0)\end{array}$ & $\begin{array}{c}0 \\
\text { (0) }\end{array}$ & $\begin{array}{c}0 \\
\text { (0) }\end{array}$ & $\begin{array}{c}3 \\
(0.3)\end{array}$ & $\begin{array}{c}32 \\
(6.7)\end{array}$ & $\begin{array}{c}39 \\
(36.4)\end{array}$ & $\begin{array}{c}7 \\
(77.8)\end{array}$ & $\begin{array}{c}81 \\
(1.7)\end{array}$ \\
\hline & & $\begin{array}{c}517 \\
(10.7)\end{array}$ & $\begin{array}{c}1216 \\
(25.1)\end{array}$ & $\begin{array}{c}1532 \\
(31.6)\end{array}$ & $\begin{array}{c}986 \\
(20.3)\end{array}$ & $481(9.9)$ & $\begin{array}{l}107 \\
(2.2)\end{array}$ & $\begin{array}{c}9 \\
(0.2)\end{array}$ & $\begin{array}{l}4848 \\
(100)\end{array}$ \\
\hline
\end{tabular}

Tablo 7'de matematik ve problem çözme puanları PISA puan kategorilere göre dağılımları bulunmaktadır. Hücrelerdeki sayılar, o kategorideki birey sayısını, parantez içindekiler ise birey sayısının ilgili sütundaki toplam birey sayısı içerisindeki yüzdesini ifade etmektedir. Dolayısıyla, parantez içerisindeki sayılar, matematik puan kategorilerindeki bireylerin problem çözme kategorilerindeki dağılımını belirtmektedir. Buna göre üst kategorilerde birey sayısının oldukça az olduğu söylenebilir. Hem problem çözme hem de matematik puanlarına göre aynı kategoride olan bireyler incelendiğinde birinci kategori için \%68.9, ikinci kategori için \%47.3, üçüncü kategori için \%42.2, dördüncü kategori için \%39.2, beşinci kategori için \%37.6, altıncı kategori için \%36.4 ve yedinci kategori için $\% 77.8$ olduğu söylenebilir. Genel uyum tüm kategorilerdeki uyumlu bireylerin yüzdesi olarak değerlendirildiğinde \%45.1 olduğu söylenebilir. Beklenti tablosu olasılık anlamı da taşıdığından örneğin problem çözme puanı açısından 4. kategoride bulunan bir bireyin matematik puanı açısından 4. kategoride olma olasılığı \%39.24'tür (387/986=0.3924). Benzer şekilde düşünüldüğünde 5. kategoride olma olasılığı ise \%21.50'dir (212/986=0.2150). Tablo 7'ye göre oluşturulan damlacık grafiği Şekil 11'de sunulmuştur. 


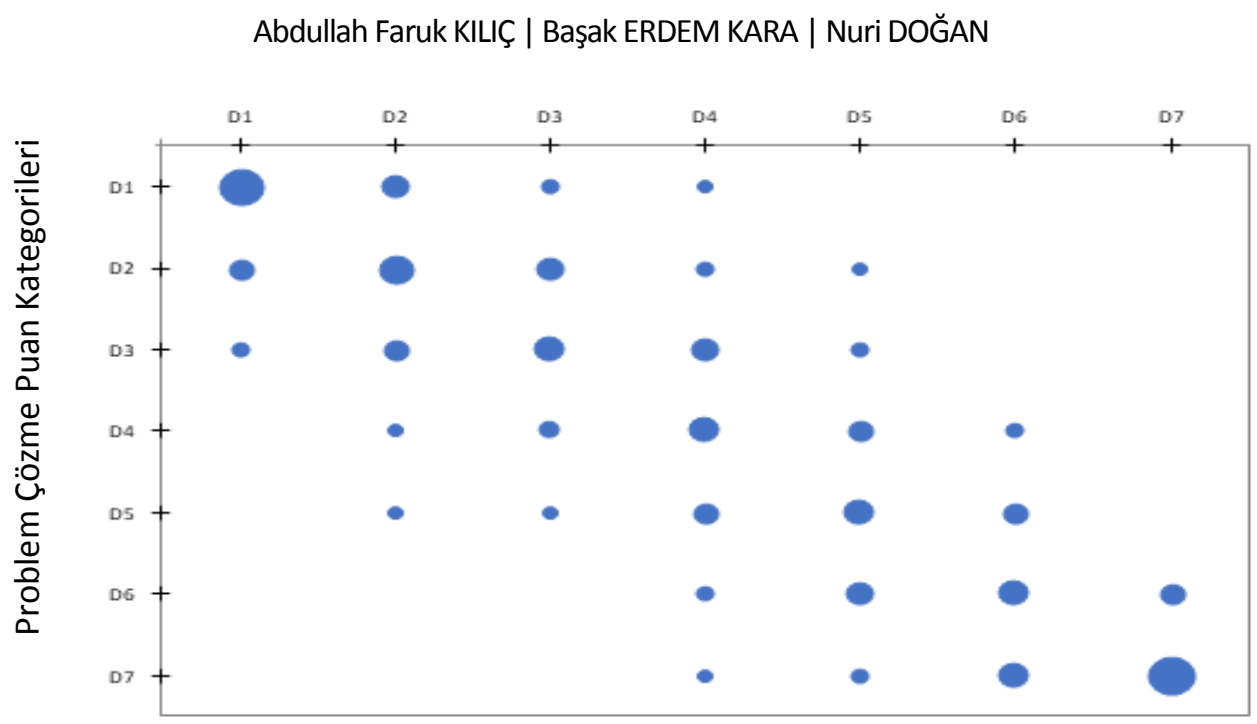

Matematik Puan Kategorileri

Şekil 11. PISA 2012 Matematik ve Problem Çözme Puanları PISA Kategorilerine Göre Karşılaştırilması

Şekil 11 incelendiğinde, PISA 2003'e ait olan Şekil 9'a benzer olarak üst uç kısımda en yüksek uyum sağlandığı görülmüştür. Köşegenlerdeki damlacıklara bakıldığında, her bir kategori düzeyindeki en yüksek damlacıkların sağlandığı görülmüştür. Bu durum, matematik puanı açısından herhangi bir kategoride yer alan bireylerin problem çözme kategorisinde de aynı kategoride yer alma olasılıklarının yüksek olduğunun göstergesi olarak kabul edilebilir. Buna göre, PISA 2003'e göre PISA 2012'de matematik puanları ile problem çözme becerileri arasındaki uyumun daha fazla olduğu söylenebilir. Bireylerin PISA puan kategorilerine göre matematik ve problem çözme puanları arasındaki uyumun belirlenmesine yönelik yürütülen uyum analizi sonucunda değişken kategorilerinin düzlemde gösterimi Şekil 12'de sunulmuştur. 


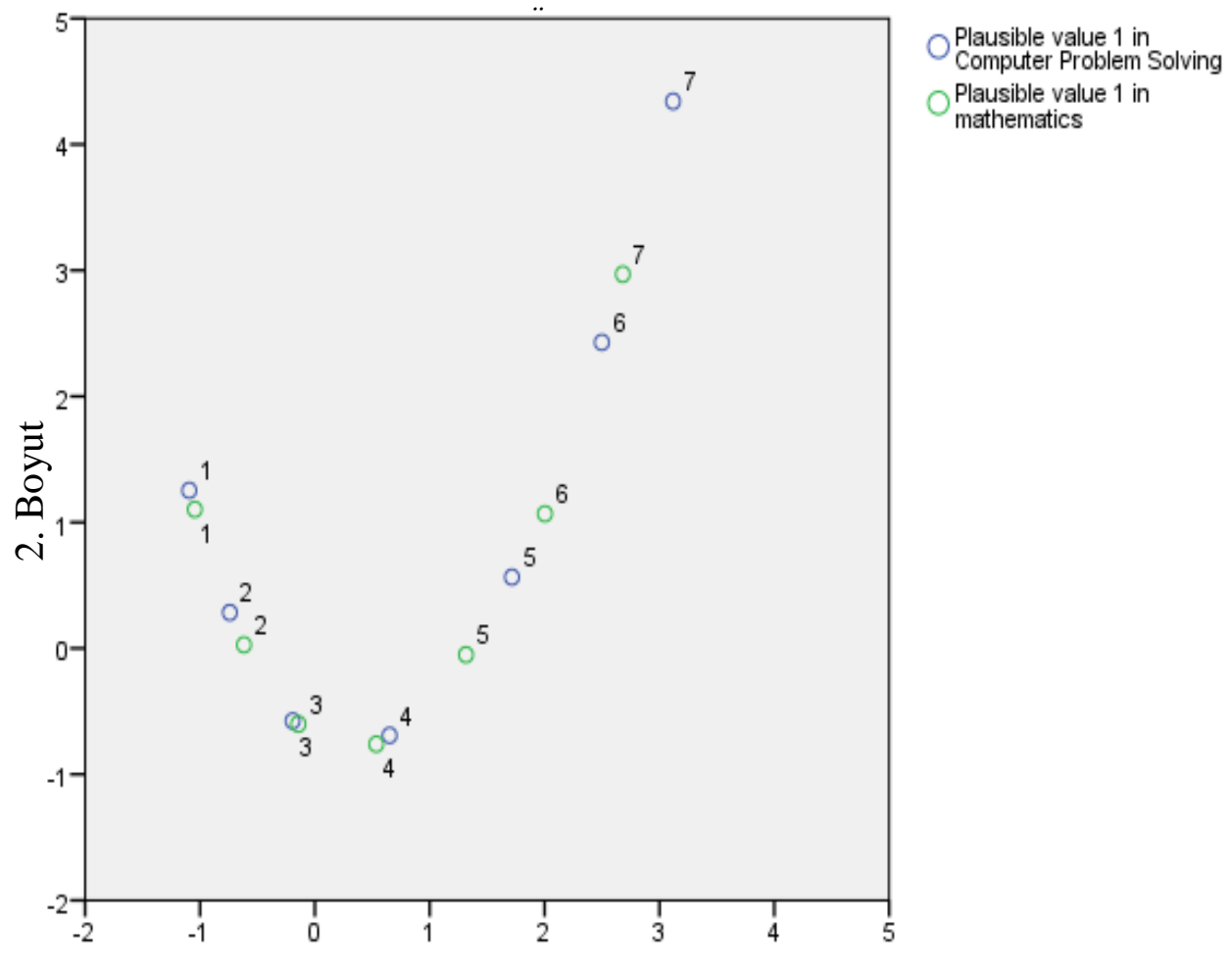

1. Boyut

Şekil 12. PISA 2012 Matematik ve Problem Çözme Puanları PISA Puan Kategorilerine Göre Değişken Kategorilerinin Düzlemde Gösterimi

Şekil 12 incelendiğinde uyum analizi sonucunda 3. ve 4. Kategorilerin uyumlarının nispeten daha iyi olduğu söylenebilir. Ancak matematik ve problem çözme puanları kategorilerinin dağılımda oldukça farklılık bulunduğundan uyum analizinin Tablo 7'deki sıfır değerlerinden etkilenebileceği unutulmamalıdır.

\section{Sonuç ve Öneriler}

PISA 2003 ve 2012 matematik okuryazarlığının ölçüt geçerliğinin incelenmesi amacıyla yürütülen bu araştırmada ölçüt puanları PISA 2003 ve 2012 problem çözme becerisi puanları olarak ele alınmıştır. Puan aralıkları \%10, \%20 ve PISA puan kategorileri olacak şekilde kategorize edilmiştir. Araştırma sonucunda PISA 2003 ve 2012 matematik okuryazarlığı puanlarının \%10'luk puan dilimine göre orta düzeydeki kategorilerde ayrışma olmasına rağmen alt ve üst kategorilerde daha iyi bir uyum olduğu gözlenmiştir. \%20'lik puan dilimleri incelendiğinde puan aralıklarının geniş olması nedeniyle \%10'luk dilimden daha iyi bir uyum olduğu söylenebilir. \%10'luk puan dilimi için bireylerin genel uyum yüzdeleri PISA 2003 ve 2012 'de sırasılyla $\% 23,5$ ve $\% 29$ iken, \%20'lik puan diliminde $\% 54$ ve \%50,2'dir. PISA puan kategorileri kullanıldığında da, PISA 2003 ve PISA 2012 problem çözme becerileri kategorileriyle matematik okuryazarlığı kategorilerinin benzer olduğu söylenebilir. 
OECD raporlarında da problem çözme becerisi yüksek olan bireylerin diğer alanlarda da iyi sonuç aldıkları; zayıf bireylerin ise diğer alanlardaki sonuçlarının da zayıf olduğu gözlenmiştir (OECD, 2005a, 2014). Mevcut araştırmanın bu açıdan literatürle uyumlu olduğu söylenebilir. PISA 2012'de alt ve üst kategorilerdeki uyumun 2003'e göre daha yüksek olduğu ifade edilebilir. Bu yorumlardan yola çıkılarak, her iki yıl için de genel anlamda matematik okuryazarlığının, problem çözme becerileriyle benzer olduğu, diğer bir deyişle matematik okuryazarlığının zamandaş geçerliğinin sağlandığı söylenebilir. Ayrıca PISA puan kategorileri kullanıldığında üst kategorideki birey sayıSı çok azaldığı için uyum analizini sonuçlarının dikkatli değerlendirilmesi gerekmektedir. Alt kategoride çok fazla bireyin bulunması, üst kategorilerde az sayıda bireyin bulunması grafiklerin okunmasında da problemlere neden olabilir. Genel olarak değerlendirildiğinde PISA 2003 ve 2012 matematik okuryazarlığı puanlarının ölçüt geçerliğinin yeterli düzeyde olduğu söylenebilir. Akyüz ve Pala (2010) tarafından yürütülen araştırmada da matematik okuryazarlığı ve problem çözme arasında yüksek etki büyüklüğünde anlamlı ilişki olduğu raporlanmıştır. Araştırmanın bu açından da literatürle uyumlu olduğu söylenebilir.

Literatürde doğrudan PISA matematik testi puanlarının ölçüt geçerliğine yönelik bir çalışmaya rastlanmamasına rağmen benzer çalışmalara atıfta bulunularak sonuçlar tartışılmıştır. Ancak doğrudan ilişkili bir çalışma olmaması nedeniyle bu çalışmalarla ilgili ayrıntılara yer verilmemiştir. Bundan sonraki araştırmalarda yordama geçerliğine yönelik araştırmalar yapılabilir.

\section{Kaynaklar}

Akyüz, G. ve Pala, N. M. (2010). PISA 2003 sonuçlarına göre öğrenci ve sınıf özelliklerinin matematik okuryazarlığına ve problem çözme becerilerine etkisi. Elementary Education Online, 9(2), 668-678.

Alpar, R. (2013). Uygulamalı çok değişkenli istatistiksel yöntemler (4. Baskı). Ankara: Detay.

Autor, D. H., Levy, F. ve Murnane, R. J. (2003). The skill content of recent technological change: An empirical exploration. The Quarterly Journal of Economics, 118(4), 1279-1333. http://www.jstor.org/stable/25053940 adresinden erişildi.

Bartholomew, D. J., Steele, F., Moustaki, I. ve Galbraith, J. I. (2008). Analysis of multivariate social science data (2. Baskı). Florida: Chapman \& Hall.

Bendixen, M. (1996). A practical guide to the use of correspondence analysis in marketing research. Marketing Research On-Line, 1, 16-38.

Clausen, S.-E. (1998). Applied correpondence analysis: An introduction. California: Sage Publications.

Greenacre, M. (2007). Correspondence analysis in practice (2. Baskı). London: Chapman \& Hall. 
Greiff, S., Wüstenberg, S., Goetz, T., Vainikainen, M.-P., Hautamäki, J., \& Bornstein, M.H. (2015). A longitudinal study of higher-order thinking skills: working memory and fluid reasoning in childhood enhance complex problem solving in adolescence. Frontiers in Psychology, 6. doi:10.3389/fpsyg.2015.01060

Hancock, G.R., \& Mueller, R. O. (2013). Structural equating modelling: A second course (2. Baskı). Charlotte, NC: Information Age.

Karasar, N. (2014). Bilimsel araştırma yöntemi (26. Baskı). Ankara: Nobel.

Latham, G.P., \& Whyte, G. (1994). The futulity of utility analysis. Personnel Psychology, 47(1), 3146. doi:10.1111/j.1744-6570.1994.tb02408.x

Murphy, K.R., \& Davidshofer, C.O. (2004). Psychological testing principles and applications (6. Baskı). Phoenix: Prentice Hall.

NCTM (The National Council of Teachers of Mathematics). (2000). Principle and standards for school mathematics. Reston: The National Council of Teachers of Mathematics.

OECD (Organisation for Economic Co-operation and Development). (2005a). PISA 2003 technical report. PISA. OECD Publishing. doi:10.1787/9789264010543-en

OECD (Organisation for Economic Co-operation and Development). (2005b). Database - PISA 2003. 12 Ekim 2018 tarihinde https://www.oecd.org/pisa/pisaproducts/databasepisa2003.htm adresinden erişildi.

OECD (Organisation for Economic Co-operation and Development). (2013). PISA 2012 assessment and analytical framework: Mathematics, reading, science, problem solving and financial literacy. PISA. OECD Publishing. doi:10.1787/9789264190511-en

OECD (Organisation for Economic Co-operation and Development). (2014). PISA 2012 technical report. OECD Publishing. https://www.oecd.org/pisa/pisaproducts/PISA-2012-technicalreport-final.pdf adresinden erişildi.

OECD (Organisation for Economic Co-operation and Development). (2015). Data base - PISA 2012.

OECD (Organisation for Economic Co-operation and Development). (2017). PISA 2015 technical report. OECD Publishing. http://www.oecd.org/pisa/sitedocument/PISA-2015-technicalreport-final.pdf adresinden erişildi.

Schrader, W.B. (1965). A taxonomy of expectancy tables. Journal of Educational Measurement, 2(1), 29-35. doi:10.1111/j.1745-3984.1965.tb00388.x

Tabachnik, B.G., \& Fidell, L.S. (2012). Using multivariate statistics (6. ed.). Boston: Pearson.

Taş, U. E., Arıcı, Ö., Ozarkan, H. B. ve Özgürlük, B. (2016). Uluslararasi öğrenci değerlendirme programi PISA 2015 ulusal raporu. Ankara: Millî Eğitim Bakanlığı. 
http://odsgm.meb.gov.tr/test/analizler/docs/PISA/PISA2015_Ulusal_Rapor.pdf adresinden erişildi.

Thomson, S., Hillman, K., \& De-Bortoli, L. (2013). A teacher's guide to PISA mathematical literacy. Victoria: ACER. https://www.acer.org/files/PISA_Thematic_Report_-_Maths_-_web.pdf adresinden erişildi.

Wüstenberg, S., Greiff, S., \& Funke, J. (2012). Complex problem solving - More than reasoning? Intelligence, 40(1), 1-14. doi:10.1016/j.intell.2011.11.003

Yavuz, E. ve Çetin, B. (2017). PISA 2012 problem çözme okuryazarlığına etki eden okul değişkenlerinin incelenmesi: Türkiye-Sırbistan karşılaştırması. Eğitimde ve Psikolojide Ölçme ve Değerlendirme Dergisi, 8(4), 435-453. doi:10.21031/epod.334610. 